\title{
Budget of nitrous acid (HONO) and its impacts on atmospheric oxidation capacity at an urban site in the fall season of Guangzhou, China
}

Yihang Yu ${ }^{1,2, \dagger}$, Peng Cheng ${ }^{1,2, *, \dagger}$, Huirong $\mathrm{Li}^{1,2}$, Wenda Yang ${ }^{1,2}$, Baobin Han ${ }^{1,2}$, Wei Song ${ }^{3}$, Weiwei Hu ${ }^{3}$, 5 Xinming Wang ${ }^{3}$, Bin Yuan ${ }^{4,5}$, Min Shao ${ }^{4,5}$, Zhijiong Huang ${ }^{4}$, Zhen Li ${ }^{4}$, Junyu Zheng ${ }^{4,5}$, Haichao Wang ${ }^{6}$ and Xiaofang $\mathrm{Yu}^{1,2}$

\begin{abstract}
${ }^{1}$ Institute of Mass Spectrometry and Atmospheric Environment, Jinan University, Guangzhou 510632, China
${ }^{2}$ Guangdong Provincial Engineering Research Center for Online Source Apportionment System of Air Pollution, Guangzhou 510632, China
\end{abstract}

$10{ }^{3}$ State Key Laboratory of Organic Geochemistry, Guangzhou Institute of Geochemistry, Chinese Academy of Sciences, Guangzhou 510640, China

${ }^{4}$ Institute for Environmental and Climate Research, Jinan University, Guangzhou 511443, China

${ }^{5}$ Guangdong-Hongkong-Macau Joint Laboratory of Collaborative Innovation for Environmental Quality, Guangzhou 511443, China

$15{ }^{6}$ School of Atmospheric Sciences, Sun Yat-Sen University, Zhuhai, China.

$\dagger$ These authors contribute equally to this paper.

* Correspondence to: Peng Cheng (chengp@jnu.edu.cn)

Abstract. Nitrous acid (HONO) can produce hydroxyl radicals $(\mathrm{OH})$ by photolysis and plays an important role in atmospheric photochemistry. Over the years, high concentrations of HONO have been observed in the Pearl River Delta region (PRD) of China, which may be one reason for the elevated atmospheric oxidation capacity. A comprehensive atmospheric observation campaign was conducted at an urban site in Guangzhou from 27 September to 9 November 2018. During the period, HONO was measured from 0.02 to $4.43 \mathrm{ppbv}$ with an average of $0.74 \pm 0.70 \mathrm{ppbv}$. The emission ratios (HONO/NOx) of $0.9 \pm 0.4 \%$ were derived from 11 fresh plumes. The primary emission rates of HONO at night were calculated to be between $0.04 \pm 0.02 \mathrm{ppbv} \mathrm{h}^{-1}$ and $0.30 \pm 0.15 \mathrm{ppbv} \mathrm{h}^{-1}$ based on a high-resolution emission inventory. The

25 HONO formation rate by the homogeneous reaction of $\mathrm{OH}+\mathrm{NO}$ at night was $0.26 \pm 0.08 \mathrm{ppbv} \mathrm{h}^{-1}$, which can be seen as secondary results from primary emission. They were both much higher than the increase rate of HONO $\left(0.02 \mathrm{ppbv} \mathrm{h}^{-1}\right)$ during night. The soil emission rate of HONO at night was calculated to be $0.019 \pm 0.001 \mathrm{ppbv} \mathrm{h}^{-1}$. Assuming dry deposition as the dominant removal process of HONO at night, a deposition velocity of at least $\sim 2.5 \mathrm{~cm} \mathrm{~s}^{-1}$ is required to balance the direct emissions and $\mathrm{OH}+\mathrm{NO}$ reaction. Correlation analysis shows that $\mathrm{NH}_{3}$ and relative humidity $(\mathrm{RH})$ may participate in

30 the heterogeneous transformation from $\mathrm{NO}_{2}$ to $\mathrm{HONO}$ at night. In the daytime, the average primary emission $\mathrm{P}_{\mathrm{emis}}$ was 0.12 $\pm 0.01 \mathrm{ppbv} \mathrm{h}^{-1}$, and the homogeneous reaction $\mathrm{P}_{\mathrm{OH}+\mathrm{NO}}$ was $0.79 \pm 0.61 \mathrm{ppbv} \mathrm{h}^{-1}$, larger than the unknown sources $\mathrm{P}_{\text {Unknown }}$ $\left(0.65 \pm 0.46 \mathrm{ppbv} \mathrm{h}^{-1}\right)$. These results suggest primary emissions as a key factor affecting HONO at our site, both during daytime and nighttime. Similar to previous studies, the daytime unknown source of HONO, $\mathrm{P}_{\text {Unknown, appeared to be related }}$ 
to the photo-enhanced conversion of $\mathrm{NO}_{2}$. The daytime average $\mathrm{OH}$ production rates by photolysis of $\mathrm{HONO}$ was $3.7 \times 10^{6}$

$\mathrm{cm}^{-3} \mathrm{~s}^{-1}$, lower than that from $\mathrm{O}^{1} \mathrm{D}+\mathrm{H}_{2} \mathrm{O}$ at $4.9 \times 10^{6} \mathrm{~cm}^{-3} \mathrm{~s}^{-1}$. Simulations of $\mathrm{OH}$ and $\mathrm{O}_{3}$ with the Master Chemical Mechanism (MCM) box model suggested strong enhancement effect of $\mathrm{HONO}$ on $\mathrm{OH}$ and $\mathrm{O}_{3}$ by $59 \%$ and $68.8 \%$, respectively, showing a remarkable contribution of HONO to the atmospheric oxidation in the fall season of Guangzhou.

Keywords: HONO; Atmospheric oxidation capacity; Budget analysis; Heterogeneous reaction

\section{Introduction}

As a primary source of hydroxyl radical $(\mathrm{OH})$, HONO has attracted scientific researchers' great interest. The photolysis of HONO (Reaction R1) can generate a substantial amount of $\mathrm{OH}$, which is a primary atmosphere oxidant that is responsible for oxidizing and removing of most natural and anthropogenic trace gases. Additionally, $\mathrm{OH}$ radicals can initiate the oxidation of the volatile organic compounds (VOC) to produce hydroperoxyl radicals $\left(\mathrm{HO}_{2}\right)$ and organic peroxy radicals $\left(\mathrm{RO}_{2}\right)$. These free radicals can further lead to the formation of ozone $\left(\mathrm{O}_{3}\right)$ in the presence of nitrogen oxides (NOx) (Xue et al., 2016; Finlayson-Pitts and Pitts, 2000; Hofzumahaus et al., 2009; Lelieveld et al., 2016; Tan et al., 2018). Up to 33-92\% $\mathrm{OH}$ formation can be attributed to HONO photolysis in both rural and urban sites (Kleffmann et al., 2005; Michoud et al., 2012; Tan et al., 2017; Xue et al., 2020; Hendrick et al., 2014). However, the detailed formation mechanisms of HONO are still not well understood and the observed HONO concentrations cannot be completely explained by current research (Sörgel et al., 2011a; Kleffmann et al., 2005; Sarwar et al., 2008; Liu et al., 2019a; Lee et al., 2016; Liu et al., 2020c).

$\mathrm{HONO}+h v \rightarrow \mathrm{OH}+\mathrm{NO}(300 \mathrm{~nm}<\lambda<405 \mathrm{~nm})$

HONO sources generally include direct emissions, homogeneous reactions and heterogeneous reactions. HONO can be directly emitted into the troposphere from combustion processes such as biomass burning, vehicle exhaust, domestic heating, and industrial exhaust (Liu et al., 2019b; Neuman et al., 2016; Nie et al., 2015; Kramer et al., 2020). The emission ratios of HONO/NOx of traffic sources have been estimated in the range of $0.3 \%-0.85 \%$ through tunnel experiments considering various engine types (Kirchstetter et al., 1996; Kurtenbach et al., 2001; Kramer et al., 2020). Soil nitrite formed through the processes of biological nitrification and denitrification, were proposed to be a prominent HONO source in the troposphere (Maljanen et al., 2013; Oswald et al., 2013; Wu et al., 2019; Su et al., 2011). Subsequently, biological soil crusts (biocrusts) were also found to release HONO (Weber et al., 2015; Porada et al., 2019; Meusel et al., 2018). In addition, an acid displacement mechanism has also been suggested to contribute substantial fraction of daytime HONO formation (VandenBoer et al., 2015). The reaction between $\mathrm{NO}$ and $\mathrm{OH}$ is considered an important pathway of HONO formation when $\mathrm{OH}$ and NO concentrations are relatively high (Alicke et al., 2002; Li et al., 2012; Pagsberg et al., 1997; Qin et al., 2009;

65 Wong et al., 2011), whereas this pathway often cannot explain the observed HONO concentrations, especially during 
daytime (Tang et al., 2015; Li et al., 2010; Czader et al., 2012; Tong et al., 2016). Bejan et al. (2006) studied the HONO formation by the photolysis of different gaseous nitrophenols and proposed that the photolysis of nitrophenols can partly explain the observed HONO formation in the urban atmosphere. Li et al. (2008) suggested that the homogeneous reaction between water vapor $\left(\mathrm{H}_{2} \mathrm{O}\right)$ and electronically excited $\mathrm{NO}_{2}(\lambda>420 \mathrm{~nm})$ can form $\mathrm{OH}$ and $\mathrm{HONO}$. While the reaction rate and yield of this reaction are still under discussion (Carr et al., 2009), and this formation mechanism can only marginally contribute to the formation of atmospheric HONO (Amedro et al., 2011; Crowley and Carl, 1997; Sörgel et al., 2011a; Wong et al., 2011; Dillon and Crowley, 2018). Zhang and Tao (2010) proposed that HONO can form through homogeneous nucleation of $\mathrm{NH}_{3}, \mathrm{NO}_{2}$ and $\mathrm{H}_{2} \mathrm{O}$. However, this reaction has not yet been observed in field experiments nor tested by laboratory studies. $\mathrm{Li}$ et al. (2014b) proposed that the reaction of $\mathrm{NO}_{2}$ with $\mathrm{HO}_{2} \cdot \mathrm{H}_{2} \mathrm{O}$ could be a gas-phase source of $\mathrm{HONO}$ in the lower troposphere. But Ye et al. (2015) estimated the $\mathrm{HONO}$ yield of the reaction of $\mathrm{NO}_{2}$ with $\mathrm{HO}_{2} \cdot \mathrm{H}_{2} \mathrm{O}$ was only $3 \%$. Additionally, heterogeneous reactions on different kinds of surfaces have also been found to be possible significant HONO sources, including heterogeneous reactions of $\mathrm{NO}_{2}$ on ground surfaces (Meusel et al., 2016; VandenBoer et al., 2013), building surfaces (Acker et al., 2006; Indarto, 2012), ocean surfaces (Wen et al., 2019; Wojtal et al., 2011; Yang et al., 2021a), soil surfaces (Laufs et al., 2017; Kleffmann et al., 2003; Yang et al., 2021b) and vegetation surfaces (Stutz et al.,

80 2002), etc. Photosensitized reduction reaction of $\mathrm{NO}_{2}$ on organic surfaces (such as humic acids and aromatics) has been considered as an effective pathway to generate HONO (George et al., 2005; Stemmler et al., 2006; Liu et al., 2020a; Ammar et al., 2010; Brigante et al., 2008; Cazoir et al., 2014; Sosedova et al., 2011). The heterogeneous conversion of $\mathrm{NO}_{2}$ to HONO on humid surfaces have also been studied (Finlayson-Pitts et al., 2003; Ammann et al., 1998; Ndour et al., 2008) and this conversion can be further promoted by ambient $\mathrm{NH}_{3}$ and $\mathrm{SO}_{2}$ (Ge et al., 2019; Wang et al., 2016; Xu et al., 2019; Li et 85 al., 2018b). In addition, HONO can also be formed by heterogeneous conversion of $\mathrm{NO}_{2}$ on secondary organic aerosols and fresh soot particles (Arens et al., 2001; Ziemba et al., 2010), but the contributions and mechanisms are still under discussion (Arens et al., 2001; Aubin and Abbatt, 2007; Bröske et al., 2003; Qin et al., 2009). Both field observations and laboratory studies found that the photolysis of adsorbed $\mathrm{HNO}_{3}$ and particulate nitrate $\left(\mathrm{NO}_{3}{ }^{-}\right)$made an important contribution to $\mathrm{HONO}$ formation (Ye et al., 2016; Ye et al., 2017; Zhou et al., 2003; Zhou et al., 2002b; Zhou et al., 2011; Ziemba et al., 2010).

90 However, Laufs and Kleffmann (2016) obtained a very low $\mathrm{HNO}_{3}$ photolysis frequency in laboratory, almost two orders of magnitude lower than the result by (Zhou et al., 2003).

The Pearl River Delta (PRD) region is one of the biggest city clusters in the world with dense population and large anthropogenic emissions. Rapid economic development and urbanization have led to severe deterioration of air quality in this region, which was characterized by atmospheric "compound pollution" with concurrent high fine particulate matter $\left(\mathrm{PM}_{2.5}\right)$ and ozone $\left(\mathrm{O}_{3}\right)$ (Tang, 2004; Chan and Yao, 2008; Yue et al., 2010). While $\mathrm{O}_{3}$ has been increasing along with reduced $\mathrm{PM}_{2.5}$ over recent years in the region (Li et al., 2014a; Liao et al., 2020; Wang et al., 2009; Zhong et al., 2013; Lu et al., 2018), indicating the enhancement of atmospheric oxidation capacity. Numerous studies have observed high concentrations of atmospheric HONO in Guangzhou (Hu et al., 2002; Su et al., 2008b; Su et al., 2008a; Qin et al., 2009; Li 
100 et al., 2012). Fast $\mathrm{OH}$ production through HONO photolysis may be a key factor for the increasing atmospheric oxidation capacity and ozone concentration in this area.

In this work, we performed continuous measurements of HONO, along with trace gases, photolysis frequencies and meteorological conditions at an urban site in Guangzhou from 27 September to 9 November 2018, as part of the field campaign named "Particles, Radicals, Intermediates from oxiDation of primary Emissions in Greater Bay Area" (PRIDEGBA2018). Benefiting from numerous prior field observational studies in the PRD region, our study stands in a strong position to ensure high quality of data acquisition and analysis of HONO, along with a full suite of other chemical species, providing a unique and valuable opportunity to refine our knowledge of HONO sources and sinks, as well as the role of $\mathrm{HONO}$ in the photochemistry of $\mathrm{O}_{3}$ and $\mathrm{OH}$ in such a region with extensive air pollution as well as rigorous emission control over recent years. A high resolution $(3 \mathrm{~km} \times 3 \mathrm{~km}$ ) NOx emission inventory for the Guangzhou city (Huang et al., 2021) was used to estimate the primary emission rates of NOx and HONO, which would reduce the uncertainty of HONO primary emission rate. By analysing our observational data, both nighttime HONO formation pathways and daytime HONO budgets have been investigated in this study. The contribution of HONO photolysis to $\mathrm{OH}$ production has been calculated and compared with that of $\mathrm{O}_{3}$ photolysis. The impact of $\mathrm{HONO}$ on atmospheric oxidation capacity and $\mathrm{O}_{3}$ formation is further investigated using a chemical box model based on Master Chemical Mechanism (MCMv3.3.1).

\section{Experiment}

\subsection{Observation site}

The sampling site $\left(23.14^{\circ} \mathrm{N}, 113.36^{\circ} \mathrm{E}\right)$ is located in the Guangzhou Institute of Geochemistry Chinese Academy of

120 Sciences (GIGCAS). The instruments were deployed in the cabin on the rooftop of a seven-story building $(\sim 40 \mathrm{~m}$ above the ground). The site is surrounded by residential communities and schools, with no industrial manufacturers or power plants around, representing a typical urban environment in the PRD region. The south China Expressway and Guangyuan Expressway, both with heavy traffic loading, are located at west and south of the site, with distances of about $300 \mathrm{~m}$. As a result, the site often experienced local emissions from traffic. The location and surroundings of the site are shown in Fig. S1.

\subsection{Measurements}

HONO was measured by a custom-built LOPAP (LOng Path Absorption Photometer) based on wet chemical sampling and photometric detection (Heland et al., 2001). Ambient air is sampled into an external sampling unit consisting of two similar stripping coils in series. Almost all of the $\mathrm{HONO}$ and a small fraction of interfering substances $\left(\mathrm{PAN}, \mathrm{HNO}_{3}, \mathrm{NO}_{2}\right.$, etc.) are absorbed in solution in the first stripping coil, while in the second stripping coil only the interfering species are absorbed. To minimize the potential interferences, we assume the interferences absorbed in the first and the second coil are the same, so 
the real HONO concentration in the atmosphere is determined by subtracting the measured signal of the second coil from the measured signal of the first coil. The absorption solution R1 is a mixture reagent of 1 L hydrochloric acid ( $\mathrm{HCl})(37 \%$ volume fraction) and $100 \mathrm{~g}$ sulfanilamide dissolved in $9 \mathrm{~L}$ pure water. The dye solution R2, $2 \mathrm{~g} \mathrm{n}$-(1-naphtyl)ethylendiamine-dihydrchloride (NEDA) dissolved in $10 \mathrm{~L}$ pure water, is then reacted with the absorption solution from two stripping coils pumped by a peristaltic pump to form colored azo dye. The light-absorbing colored azo dye is then pumped through a debubbler by the peristaltic pump and flows into the detection unit, which consists of two liquid waveguide capillary cells (World Precision Instrument, LWCC), one LED light source (Ocean Optics), two miniature spectrometers (Ocean Optics, Maya2000Pro) and several optical fibers. To correct for the small zero-drifts in the instrument's baseline, the zero measurements were conducted every $12 \mathrm{~h}$ by introducing zero air (highly pure nitrogen) at a flow rate of $1 \mathrm{~L} \mathrm{~min}{ }^{-1}$.

140 During the instrument's operation, the instrument calibration was performed every week using the standard sodium nitrite $\left(\mathrm{NaNO}_{2}\right)$ solution. The detection limit, time resolution and uncertainty of the measurement were $5 \mathrm{pptv}, 15 \mathrm{~min}$ and $8 \%$, respectively. More detailed information of LOPAP instrument can be found in previous studies (Heland et al., 2001; Kleffmann et al., 2006; Kleffmann et al., 2002).

145 In addition to HONO, ambient VOCs were measured using a TH-300B On-Line VOCs Monitoring System involving detection technology of ultralow temperature preconcentration coupled with gas chromatography-mass spectrometry (GC/MS) with the time resolution of $1 \mathrm{~h}$. $\mathrm{NOx}\left(\mathrm{NO}+\mathrm{NO}_{2}\right)$ was measured by a nitrogen oxides analyzer (Thermo Scientific, Model 42i), which used a NO-NO chemiluminescence detector equipped with a molybdenum-based converter with the time resolution and detection limit of $1 \mathrm{~min}$ and 1 ppbv respectively. $\mathrm{O}_{3}$ was measured by an $\mathrm{O}_{3}$ analyzer (Thermo Scientific, Model 49i) via ultraviolet absorption method with the time resolution and detection limit of $1 \mathrm{~min}$ and 1 ppbv respectively. $\mathrm{SO}_{2}$ was measured by $\mathrm{SO}_{2}$ analyzer (Thermo Scientific, Model 43i) via pulsed fluorescence method with the time resolution and detection limit of 1 min and 1 ppbv respectively. CO was measured by a CO analyzer (Thermo Scientific, Model 48i) with the time resolution and detection limit of $1 \mathrm{~min}$ and $0.1 \mathrm{ppmv}$ respectively. $\mathrm{NH}_{3}$ was measured by laser absorption spectroscopy (PICARRO, G2508) with the time resolution and detection limit of $1 \mathrm{~min}$ and 1 ppbv respectively. Gaseous

$155 \mathrm{HNO}_{3}$ was detected by a Time-Of-Flight Chemical Ionization Mass Spectrometer (Aerodyne Research Inc., TOF-CIMS) with a time resolution of $1 \mathrm{~min}$. And particulate nitrate $\left(\mathrm{NO}_{3}{ }^{-}\right)$was measured by Time-Of-Flight Accelerator Mass Spectrometry (Aerodyne Research Inc., TOF-AMS) with a time resolution of 1 min. $\mathrm{PM}_{2.5}$ was measured by a Beta Attenuation Monitor (MET One Instruments Inc., BAM-1020) with the time resolution and detection limit of $1 \mathrm{~h}$ and $4.0 \mu \mathrm{g}$ $\mathrm{m}^{-3}$ respectively. The meteorological data, including temperature $(\mathrm{T})$, relative humidity $(\mathrm{RH})$ and wind speed and direction

160 (WS, WD) were recorded by Vantage Pro2 Weather Station (Davis Instruments Inc., Vantage Pro2) with the time resolution of 1 min. Photolysis frequencies including $\mathrm{J}(\mathrm{HONO}), \mathrm{J}\left(\mathrm{NO}_{2}\right), \mathrm{J}\left(\mathrm{H}_{2} \mathrm{O}_{2}\right)$ and $\mathrm{J}\left(\mathrm{O}^{1} \mathrm{D}\right)$ were measured by a filter radiometry (Focused Photonics Inc., PFS-100) with a time resolution of 1 min. 


\subsection{Box model}

To evaluate the influence of HONO chemistry on the atmospheric oxidation capacity, a zero dimensional box model based

on the Master Chemical Mechanism (MCMv3.3.1) (Jenkin et al., 2015; Jenkin et al., 2003; Saunders et al., 2003) was applied to calculate the concentrations of $\mathrm{O}_{3}$ and $\mathrm{OH}$ radicals. The Master Chemical Mechanism describes atmospheric gasphase organic chemistry in detail which has been widely used in atmospheric chemistry modelling. Kinetic rate coefficients were derived from the MCM v3.3.1 website (http://mcm.leeds.ac.uk/MCM). In this work, the boundary layer diurnal cycle has been modified and the dilution factor $\mathrm{k}_{\mathrm{dil}}$ was set at $86400^{-1} \mathrm{~s}$. The solar altitude was calculated based on longitude, latitude and time of the observation. Photolysis rate correction coefficient $j_{\text {corr }}$ was set to 1 . The model simulation was constrained by hourly averaged measurement data, including $\mathrm{HONO}, \mathrm{NO}, \mathrm{NO}_{2}, \mathrm{CO}, \mathrm{SO}_{2}, \mathrm{VOC}$ species, and temperature, water vapor, wind speed, wind direction, pressure and photolysis frequencies $\mathrm{J}\left(\mathrm{NO}_{2}\right), \mathrm{J}(\mathrm{HONO}), \mathrm{J}\left(\mathrm{O}^{1} \mathrm{D}\right)$ and $\mathrm{J}\left(\mathrm{H}_{2} \mathrm{O}_{2}\right)$. The simulation results were evaluated by comparing against the measurements, and index of agreement (IOA), a statistical parameter was employed for the evaluation (Jeon et al., 2018; Xing et al., 2019; Li et al., 2010). Two simulations with and without $\mathrm{HONO}$ constrained by measured values were conducted to examine the impact of $\mathrm{HONO}$ on $\mathrm{OH}$ and $\mathrm{O}_{3}$ formation.

\section{Results and discussion}

\subsection{Data overview}

The time series of meteorological parameters and pollutants during the campaign are shown in Fig. 1. The HONO concentrations ranged from 0.02 to $4.43 \mathrm{ppbv}$ with an average of $0.74 \pm 0.70 \mathrm{ppbv}$. Table 1 summarizes the HONO observations reported in PRD region since 2002. HONO appears to have shown a decreasing trend in Guangzhou, as improvement of air quality in Guangzhou was witnessed during the past decade. Spikes of NO occurred frequently, even up to $134.8 \mathrm{ppbv}$, as a result of traffic emissions from two major roads near the site. The concentrations of $\mathrm{NO}_{2}, \mathrm{SO}_{2}, \mathrm{NH}_{3}$ and $\mathrm{PM}_{2.5}$ ranged from 5.4-102.0 ppbv, 0-6.3 ppbv, 2.8-7.8 ppbv and 4-109 $\mu \mathrm{g} \mathrm{m}^{-3}$ respectively with the average values of 50.8 $\pm 17.2 \mathrm{ppbv}, 1.9 \pm 1.2 \mathrm{ppbv}, 6.3 \pm 2.7 \mathrm{ppbv}$, and $36 \pm 16 \mu \mathrm{g} \mathrm{m}{ }^{-3}$ respectively. The $\mathrm{O}_{3}$ concentrations ranged from $0.3-149.8$ ppbv with an average peak concentration of $73.9 \pm 28.4 \mathrm{ppbv}$. During the observation, the temperature ranged from $17{ }^{\circ} \mathrm{C}$ to $30{ }^{\circ} \mathrm{C}$ with an average of $24 \pm 3{ }^{\circ} \mathrm{C}$, and the relative humidity ranged from $28 \%$ to $97 \%$ with an average of $70 \pm 17 \%$. The average wind speed was $6.8 \pm 4.5 \mathrm{~m} \mathrm{~s}^{-1}$, while the maximum wind speed was $22.7 \mathrm{~m} \mathrm{~s}^{-1}$. There was a pollution period from 8th to 10th October with elevated $\mathrm{PM}_{2.5}\left(60 \pm 12 \mu \mathrm{g} \mathrm{m}^{-3}\right)$ and HONO $(0.94 \pm 0.58 \mathrm{ppbv})$. By contrast, from 29 October to 3 November, efficient ventilation driven by strong winds $\left(>11 \mathrm{~m} \mathrm{~s}^{-1}\right)$ led to low levels of most pollutants in this period, with average concentrations of $\mathrm{PM}_{2.5}$ and $\mathrm{HONO}$ at $28 \pm 11 \mu \mathrm{g} \mathrm{m}{ }^{-3}$ and $0.56 \pm 0.34 \mathrm{ppbv}$, respectively. 


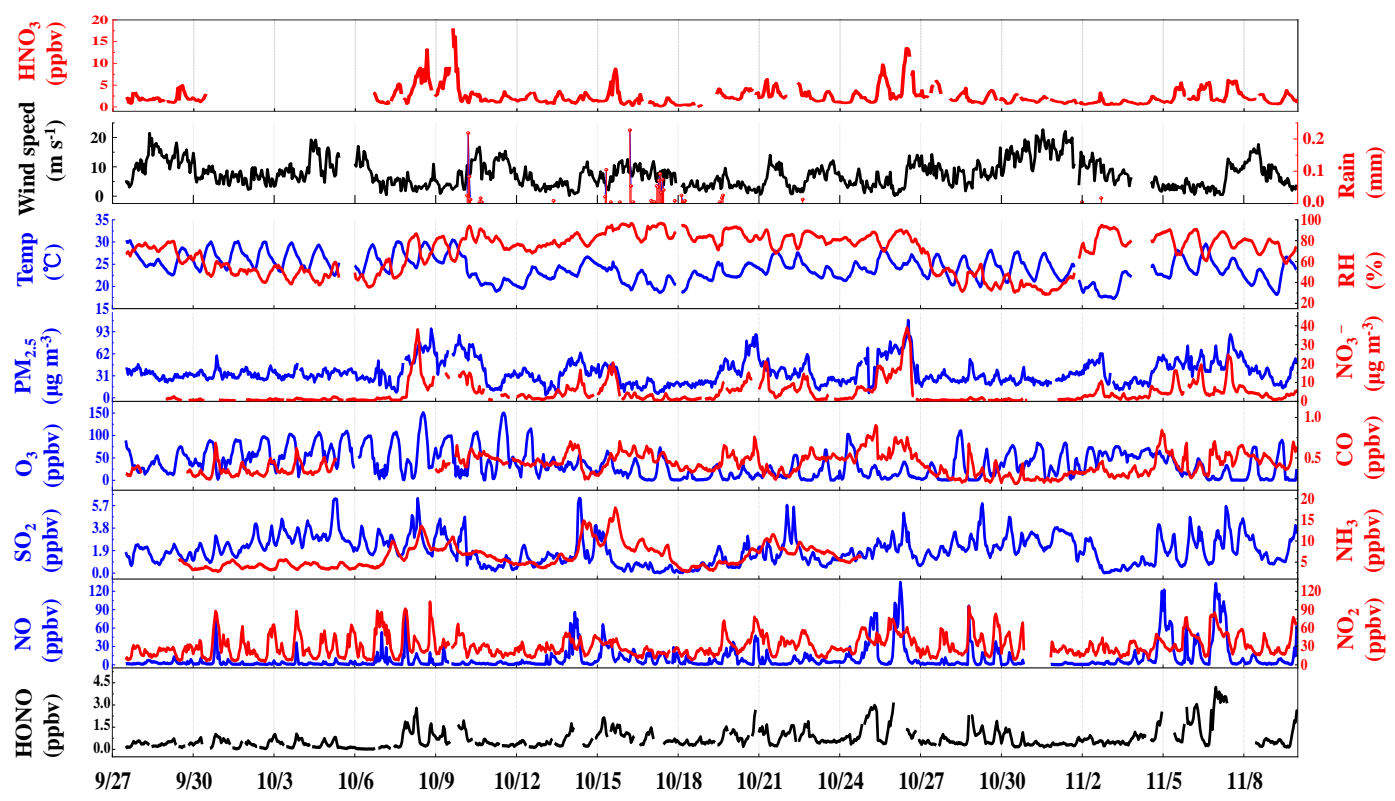

Local time [2018-mm-dd]

Figure 1. Temporal variations of meteorological and pollutants during the observation period. 
https://doi.org/10.5194/acp-2021-178

Preprint. Discussion started: 3 May 2021

(c) Author(s) 2021. CC BY 4.0 License.

Table 1. Overview of the ambient $\mathrm{HONO}, \mathrm{NO}_{2}$ and NOx measurement, as well as the ratios of $\mathrm{HONO}_{2} \mathrm{NO}_{2}$ in the PRD region ordered chronologically. Data from Guangzhou are in italic.

\begin{tabular}{|c|c|c|c|c|c|c|c|c|c|c|c|}
\hline \multirow[t]{2}{*}{ Location } & \multirow[t]{2}{*}{ Date } & \multirow[t]{2}{*}{ HONO (ppbv) } & \multicolumn{2}{|c|}{ HONO (ppbv) } & \multicolumn{2}{|c|}{$\mathrm{NO}_{2}$ (ppbv) } & \multicolumn{2}{|c|}{ NOx (ppbv) } & \multicolumn{2}{|c|}{$\mathrm{HONO} / \mathrm{NO}_{2}$} & \multirow[t]{2}{*}{ Reference } \\
\hline & & & Night & Day & Night & Day & Night & Day & Night & Day & \\
\hline Guangzhou & Jul 2002 & 1.89 & & & & & & & & & \multirow{2}{*}{1} \\
\hline (China) & Nov 2002 & 1.52 & & & & & & & & & \\
\hline $\begin{array}{l}\text { Xinken } \\
\text { (China) }\end{array}$ & Oct-Nov 2004 & 1.20 & 1.30 & 0.80 & 34.8 & 30.0 & 37.8 & 40.0 & 0.037 & 0.027 & 2 \\
\hline $\begin{array}{c}\text { Back Garden } \\
\text { (China) }\end{array}$ & Jul 2006 & 0.93 & 0.95 & 0.24 & 16.5 & 4.5 & 20.9 & 5.5 & 0.057 & 0.053 & 3 \\
\hline $\begin{array}{c}\text { Guangzhou } \\
\text { (China) }\end{array}$ & Jul 2006 & 2.80 & 3.50 & 2.00 & 20.0 & 30.0 & & & 0.175 & 0.067 & 4 \\
\hline $\begin{array}{c}\text { Guangzhou } \\
\text { (China) }\end{array}$ & Oct 2015 & 1.64 & 2.25 & 0.90 & 40.5 & 27.3 & 57.9 & 39.8 & 0.060 & 0.030 & 5 \\
\hline $\begin{array}{c}\text { Guangzhou } \\
\text { (China) }\end{array}$ & Jul 2016 & 1.03 & 1.27 & 0.70 & 35.0 & 25.9 & 66.3 & 52.1 & 0.040 & 0.070 & 6 \\
\hline This work & Sep-Nov 2018 & 0.74 & 0.91 & 0.44 & 36.9 & 23.3 & 47.7 & 30.1 & 0.026 & 0.022 & \\
\hline $\begin{array}{c}\text { Jiangmen } \\
\text { (China) }\end{array}$ & Oct-Nov 2008 & 0.60 & & 0.48 & & & & 9.1 & & & 7 \\
\hline \multirow{4}{*}{$\begin{array}{l}\text { Hong Kong } \\
\text { (China) }\end{array}$} & Aug 2011 & 0.66 & 0.66 & 0.70 & 21.8 & 18.1 & 29.3 & 29.3 & 0.031 & 0.042 & \multirow{4}{*}{8} \\
\hline & Nov 2011 & 0.93 & 0.95 & 0.89 & 27.2 & 29.0 & 37.2 & 40.6 & 0.034 & 0.030 & \\
\hline & Feb 2012 & 0.91 & 0.88 & 0.92 & 22.2 & 25.8 & 37.8 & 48.3 & 0.036 & 0.035 & \\
\hline & May 2012 & 0.35 & 0.33 & 0.40 & 14.7 & 15.0 & 19.1 & 21.1 & 0.022 & 0.030 & \\
\hline $\begin{array}{l}\text { Heshan } \\
\text { (China) }\end{array}$ & Oct 2013 & 1.57 & & & & & & & & & 9 \\
\hline $\begin{array}{l}\text { Heshan } \\
\text { (China) }\end{array}$ & Oct-Nov 2014 & 1.40 & 1.78 & 0.77 & 19.3 & 17.9 & 21.5 & 22.7 & 0.093 & 0.055 & 10 \\
\hline $\begin{array}{l}\text { Hong Kong } \\
\text { (China) }\end{array}$ & Mar-May 2015 & 3.30 & 2.86 & 3.91 & & & & & & & 11 \\
\hline
\end{tabular}

References: 1. (Hu et al., 2002); 2. (Su et al., 2008a; Su et al., 2008b); 3. (Li et al., 2012; Su, 2008); 4. (Qin et al., 2009); 5. (Tian et al., 2018); 6. (Yang et al., 2017a); 7. (Yang, 2014); 8. (Xu et al., 2015); 9. (Yue et al., 2016); 10. (Liu, 2017); 11. (Yun et al., 2017). 
The time series of photolysis frequencies $\mathrm{J}(\mathrm{HONO}), \mathrm{J}\left(\mathrm{O}^{1} \mathrm{D}\right)$ and $\mathrm{J}\left(\mathrm{NO}_{2}\right)$ in the whole observation period are shown in Fig. S2. The maximum values of $\mathrm{J}(\mathrm{HONO}), \mathrm{J}\left(\mathrm{O}^{1} \mathrm{D}\right)$ and $\mathrm{J}\left(\mathrm{NO}_{2}\right)$ are $1.58 \times 10^{-3} \mathrm{~s}^{-1}, 2.54 \times 10^{-5} \mathrm{~s}^{-1}$ and $9.31 \times 10^{-3} \mathrm{~s}^{-1}$, respectively. These $\mathbf{J}$ values tracked a similar diurnal pattern, reaching a maximum at noon with high solar radiation and decreasing to zero at night.

The diurnal variations of $\mathrm{HONO}, \mathrm{NO}_{2}, \mathrm{HONO} / \mathrm{NO}_{2}$, and $\mathrm{NO}$ are shown in Fig. 2. A daytime trough and a night-time peak of HONO were observed, as typically seen in cities and rural sites (Lee et al., 2016; Xue et al., 2020; Villena et al., 2011; Yang et al., 2021c). The observed high HONO concentration around $0.5 \mathrm{ppbv}$ at daytime implies strong HONO production to balance its rapid loss through photolysis. $\mathrm{NO}_{2}$ showed a similar diurnal pattern. It is worth noting that the diurnal variation of 210 NO was quite similar to that of HONO, implying the potential association between them. Additionally, the observed large amount of $\mathrm{NO}(10.8 \pm 17.2 \mathrm{ppbv})$ at night indicates strong primary emission near the site. As an indicator of $\mathrm{NO}_{2}$ to $\mathrm{HONO}$ conversion, the ratio of $\mathrm{HONO} / \mathrm{NO}_{2}$ rose at night and decreased after sunrise due to photolysis, ranging from $1.4 \%$ to $3.0 \%$ with an average of $2.3 \pm 1.3 \%$, which is lower than most previous field observations in PRD region (Li et al., 2012; Qin et al., 2009; Xu et al., 2015), and is typical for relatively fresh plumes. Previous many field observations also reported low 215 values of $\mathrm{HONO} / \mathrm{NO}_{2}$ ranging from $2 \%$ to $10 \%$ in freshly polluted air masses (Febo et al., 1996; Lammel and Cape, 1996; Sörgel et al., 2011b; Stutz et al., 2004; Zhou et al., 2007; Su et al., 2008a). The relatively stable and low value of $\mathrm{HONO} / \mathrm{NO}_{2}$ in nighttime seems to indicate the low contribution of heterogeneous reactions of $\mathrm{NO}_{2}$ to $\mathrm{HONO}$ concentrations. 


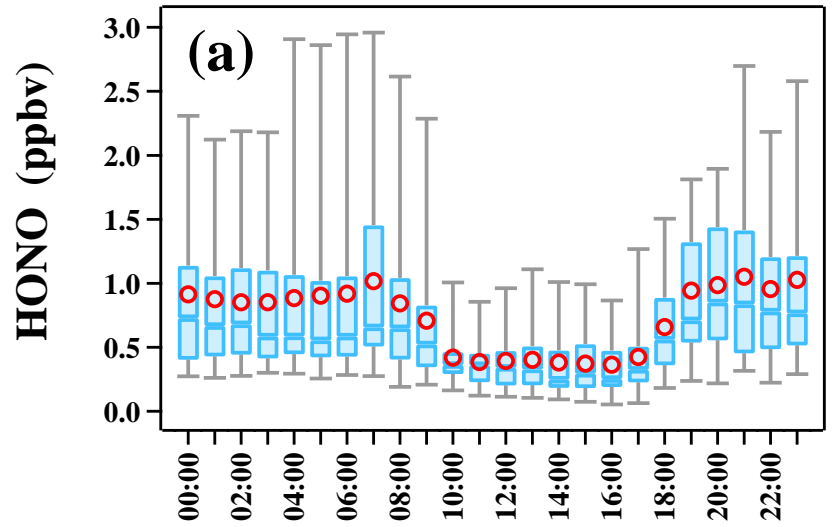

Hour

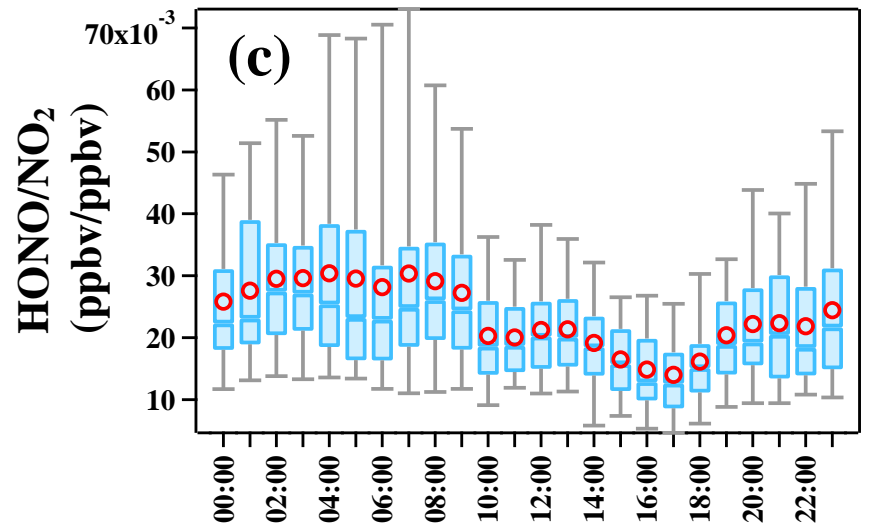

Hour

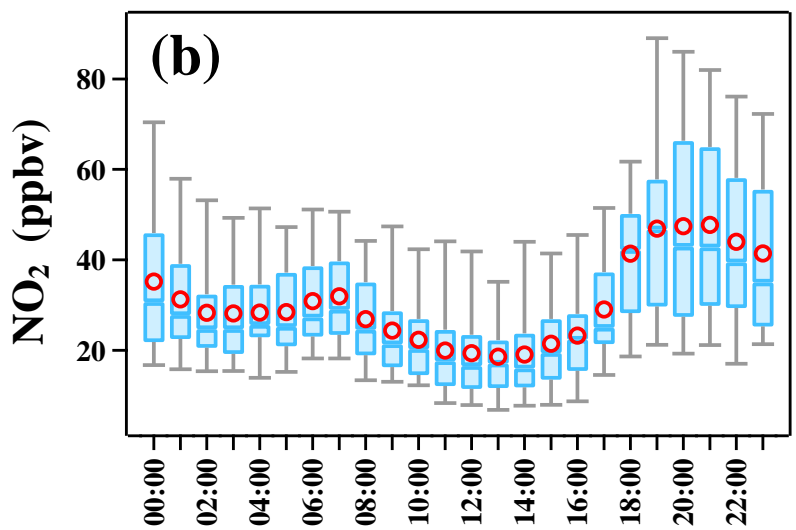

Hour

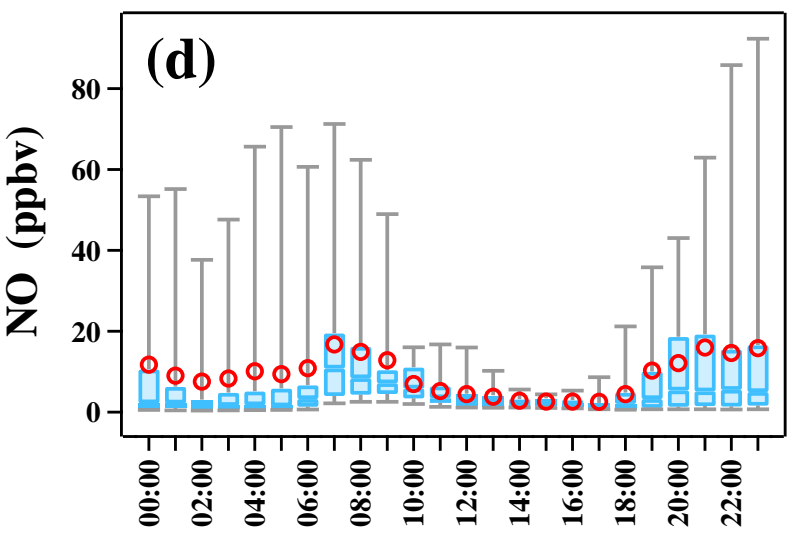

Hour

Figure 2. Diurnal profiles of $\mathrm{HONO}, \mathrm{NO}_{2}, \mathrm{NO}$ and $\mathrm{HONO} / \mathrm{NO}_{2}$ during the observation period. The blue line in the box and red circle refer to the median and mean, respectively. Boxes represent $25 \%$ to $75 \%$ of the data, and whiskers $95 \%$ of the data. The box plots presented in this study is generated by an Igor Pro-based computer program, Histbox (Wu et al., 2018).

\subsection{Nocturnal HONO formation and sources}

\subsubsection{Direct emissions}

225 As noted in Sect. 1, the site was expected to receive substantial direct emission of HONO from two major roads nearby. We obtained the emitted HONO/NOx ratios in fresh plumes defined with the following criteria (Xu et al., 2015):

(a) NOx $>49.7$ ppbv (highest $25 \%$ of NOx data);

(b) $\mathrm{NO} / \mathrm{NOx}>0.8$;

(c) good correlation between NOx and HONO $\left(\mathrm{R}^{2}>0.70\right.$, P < 0.05);

(d) short duration of plumes $(<2 \mathrm{~h})$; 
(e) global radiation $<10 \mathrm{~W} \mathrm{~m}{ }^{-2}\left(\mathrm{~J}_{\left(\mathrm{NO}_{2}\right)}<0.25 \times 10^{-3} \mathrm{~s}^{-1}\right)$.

During the campaign, 11 fresh plumes were identified to satisfy criteria (a)-(e) (see Table S1). Two cases among them are shown in Fig. S3. The HONO/NOx ratios in these selected plumes varied from $0.1 \%$ to $1.5 \%$ with an average value of $0.9 \pm$ $0.4 \%$, which is comparable to the average value of $1.2 \%$ measured in Hong Kong (Xu et al., 2015), $1.0 \%$ observed in Hong Kong (Yun et al., 2017), $0.79 \%$ measured in Nanjing (Liu et al., 2019b) and $0.69 \%$ observed in Changzhou (Shi et al., 2020b). It should be noted that the emission factor derived in this study is based on field observation and the screening criterion for fresh air mass is NO/NOx $>0.8$, while the fresh air mass was characterized by NO/NOx $>0.9$ in the tunnel experiments conducted by (Kurtenbach et al., 2001), so the air masses we selected were still slightly aged and the emission factor derived in this study is slightly overestimated.

To calculate the primary emission $\mathrm{P}_{\text {emis, }}$, three methods have been used in previous studies (Liu et al., 2019b; Liu et al., 2020b; Meng et al., 2020). In method (1), $\mathrm{P}_{\text {emis }}$ is equal to the product of emission coefficient $\mathrm{K}$ and observed NOx concentration (Cui et al., 2018; Huang et al., 2017) (see Eq. (1)). This method ignores the sink of NOx and HONO, as well as transport and 245 convection. On this basis, the observed NOx is equal to the accumulation of NOx emission, and HONO emission is linearly related to NOx concentration. However, ubiquitous loss of NOx would increase the uncertainty of this method, especially during daytime. In method (2), $\mathrm{P}_{\mathrm{emis}}$ is equal to the product of emission coefficient $\mathrm{K}$ and $\triangle \mathrm{NOx}$, the increase of NOx concentration during $\Delta \mathrm{t}$ (Liu et al., 2019b; Zheng et al., 2020) (see Eq. (2)). The promise of this method is similar to method (1), and it can only be used when NOx is increasing. As expected, a decrease in NOx would yield a negative HONO 250 emission rate, which is unrealistic. In method (3), $\mathrm{P}_{\mathrm{emis}}$ is equal to the product of emission coefficient $\mathrm{K}$ and $\mathrm{NOx}^{*}$, the NOx emission from source emission inventory (Michoud et al., 2014; Su et al., 2008b) (see Eq. (3)). This method adheres to the definition of HONO emission rate, assuming that the primary sources are evenly mixed in a specific area. It is desirable that emission inventory data with high spatial and temporal resolution are used to obtain an accurate estimate.

$\mathrm{P}_{\mathrm{emis}}=\mathrm{K} \times \mathrm{NOx}$

$\mathrm{P}_{\mathrm{emis}}=\mathrm{K} \times \Delta \mathrm{NOx}$

$\mathrm{P}_{\mathrm{emis}}=\mathrm{K} \times \mathrm{NOX} *$

In this study, we first used NOx emission rate from a high-resolution emission inventory (Huang et al., 2021) to calculate emission rate of HONO $P_{\text {emis }}$ at night (18:00-6:00). The NOx emission rate was extracted from a $3 \mathrm{~km} \times 3 \mathrm{~km}$ grid cell centred around our site. As a comparison, we also used the 2017 NOx emission inventory of Guangzhou city to repeat the calculation. The two inventories are primarily different in spatial resolution. The high-resolution $3 \mathrm{~km} \times 3 \mathrm{~km}$ data is expected to better represent local traffic emissions, whereas the city-level emission inventory represents the total emission. Since we cannot quantify the relative contribution of the local and regional emissions to this site, two results are used to 
https://doi.org/10.5194/acp-2021-178

Preprint. Discussion started: 3 May 2021

(c) Author(s) 2021. CC BY 4.0 License.

(c) (i)

265 represent upper and lower limits of the contribution of primary emissions to HONO. The nighttime height of the boundary layer is assuming to $200 \mathrm{~m}$ according to the previous study by (Fan et al., 2008).

Hourly HONO primary emission rates calculated with the two inventories are shown in Fig. 3. Pemis calculated with the highresolution emission data $(3 \mathrm{~km} \times 3 \mathrm{~km})$ shows a steep downward trend from 18:00 $\left(0.56 \mathrm{ppbv} \mathrm{h}^{-1}\right)$ to 4:00 $\left(0.14 \mathrm{ppbv} \mathrm{h}^{-1}\right)$, 270 followed by an upward trend from 4:00 $\left(0.14 \mathrm{ppbv} \mathrm{h}^{-1}\right)$ to 6:00 $\left(0.25 \mathrm{ppbv} \mathrm{h}^{-1}\right)$. The average of $\mathrm{P}_{\text {emis }}$ is $0.30 \pm 0.15 \mathrm{ppbv} \mathrm{h}^{-1}$, far larger than the average accumulating rate of $\mathrm{HONO}$ at night $\left(0.02 \mathrm{ppbv} \mathrm{h}^{-1}\right)$ derived from observed HONO variation. By contrast, $\mathrm{P}_{\mathrm{emis}}$ with the city level emission data (Guangzhou) is much lower $\left(0.04 \pm 0.02 \mathrm{ppbv} \mathrm{h}^{-1}\right)$ and varied smoothly throughout the night, but is still larger than the observed HONO accumulation rate. Direct emission of HONO appears to be a large HONO source at night along with other sources of HONO that remain to be considered. Furthermore, a large sink of 275 HONO was necessary to explain the observed trend of HONO. 


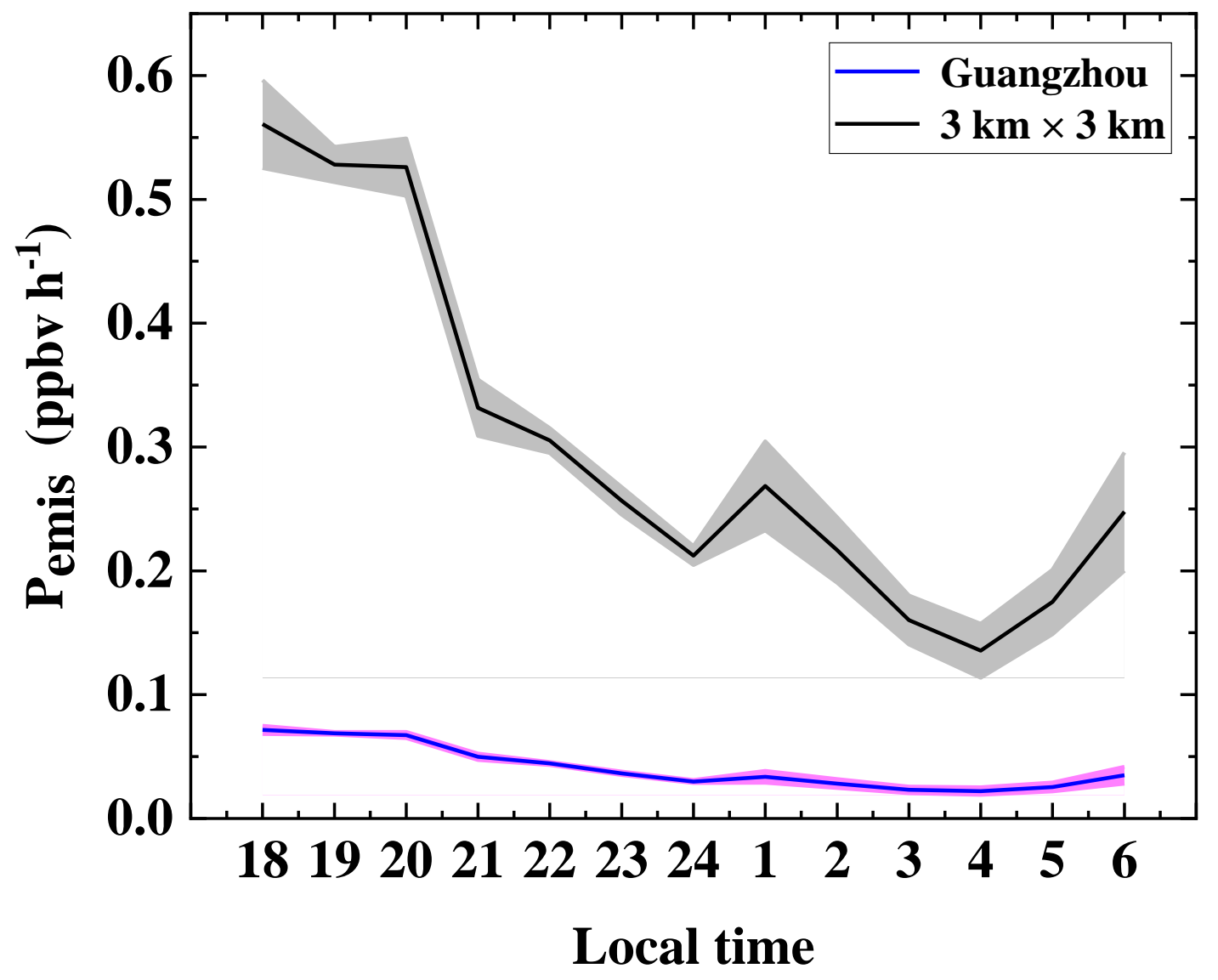

280 Figure 3. The nocturnal variation of HONO primary emission rates. The black and blue lines represent the HONO primary emission rates calculated by the 2017 NOx emission source inventory of the $3 \mathrm{~km} \times 3 \mathrm{~km}$ grid cell centred on the Guangzhou Institute of Geochemistry and the 2017 NOx emission source inventory of Guangzhou city respectively. The coloured areas represent 1 - $\sigma$ standard deviations.

Method (1) is also adopted here to calculate $\mathrm{P}_{\mathrm{emis}}$, and $\mathrm{P}_{\mathrm{emis}} / \mathrm{HONO}$ can simply represent the primary emission's contribution 285 to HONO. The ratio of $\mathrm{P}_{\mathrm{emis}} / \mathrm{HONO}$ is $47 \%$, much higher than previous estimates in Shanghai (12.5\%) (Cui et al., 2018), Ji'nan (18 \%) (Li et al., 2018a), Xi'an (23.6\%) (Huang et al., 2017) and Hong Kong (35.2\%) (Xu et al., 2015). It is possible that the observation site in this study is more strongly affected by primary emission from vehicle exhaust compared to those previous studies.

290 In addition to traffic emissions, we also estimated the $\mathrm{HONO}$ emission rate from soil $\mathrm{P}_{\text {soil }}\left(\mathrm{ppbv} \mathrm{h}^{-1}\right)$ according to Eq. (4):

$\mathrm{P}_{\text {soil }}=\frac{\alpha \mathrm{F}_{\text {soil }}}{\mathrm{H}}$ 
where $\mathrm{F}_{\text {soil }}$ is the emission flux $\left(\mathrm{g} \mathrm{m}^{-2} \mathrm{~s}^{-1}\right)$; $\mathrm{H}$ is the height of boundary layer $(\mathrm{H}, \mathrm{m})$ and was assumed to be $200 \mathrm{~m}$ (Fan et al.,

2008); $\alpha$ is the conversion factor $\left(\alpha=\frac{1 \times 10^{9} \times 3600 \times \mathrm{R} \times \mathrm{T}}{\mathrm{M} \times \mathrm{P}}=\frac{2.99 \times 10^{13} \times \mathrm{T}}{\mathrm{M} \times \mathrm{P}}\right) ; \mathrm{T}$ is the temperature $(\mathrm{K}) ; \mathrm{M}$ is the molecular weight $(\mathrm{g}$ $\mathrm{mol}^{-1}$ ) and $\mathrm{P}$ is the atmospheric pressure (Pa). HONO emission flux from soil depends on the temperature, water content and nitrogen nutrient content of soil, which have been considered according to the parameters reported in the literature (Oswald et al., 2013), assuming the site is surrounded by grassland. The water content was set at 35-45\%. The average nighttime $\mathrm{P}_{\text {soil }}$ varied from 0.011 to $0.035 \mathrm{ppbv} \mathrm{h}^{-1}$, with a mean value of $0.019 \pm 0.001 \mathrm{ppbv} \mathrm{h}^{-1}$. It is comparable to the lower limit of primary emission rate of $0.04 \pm 0.02 \mathrm{ppbv} \mathrm{h}^{-1}$.

\subsubsection{NO + OH homogeneous reaction}

300 The reaction between $\mathrm{NO}$ and $\mathrm{OH}$ acts as the principle homogenous HONO source. It can contribute a substantial fraction to HONO formation when NO and OH concentrations are high (Alicke et al., 2003; Liu et al., 2019b; Wong et al., 2011; Tong et al., 2015). Taking the homogeneous Reactions R2 and R3 into account, the net HONO homogeneous production rate can be calculated by following Eq. (5):

$305 \mathrm{NO}+\mathrm{OH} \rightarrow \mathrm{HONO}$

$\mathrm{HONO}+\mathrm{OH} \rightarrow \mathrm{NO}_{2}+\mathrm{H}_{2} \mathrm{O}$

$\mathrm{P}_{\text {net }}=\mathrm{k}_{\mathrm{NO}+\mathrm{OH}}[\mathrm{NO}][\mathrm{OH}]-\mathrm{k}_{\mathrm{HONO}+\mathrm{OH}}[\mathrm{HONO}][\mathrm{OH}]$

In Eq. (5), $\mathrm{k}_{\mathrm{NO}+\mathrm{OH}}\left(7.2 \times 10^{-12} \mathrm{~cm}^{3} \mathrm{~s}^{-1}\right)$ and $\mathrm{k}_{\mathrm{HONO}}+\mathrm{OH}\left(5.0 \times 10^{-12} \mathrm{~cm}^{3} \mathrm{~s}^{-1}\right)$ are the reaction rate constants of the Reactions

$310 \mathrm{R} 2$ and R3 at $298 \mathrm{~K}$, respectively (Li et al., 2012). Since the $\mathrm{OH}$ concentration was not measured, an average nighttime value of $1.0 \times 10^{6} \mathrm{~cm}^{-3}$ measured in Heshan in the PRD region in autumn of 2014 was assumed (Liu, 2017). As shown in Fig. 4, the variation of $\mathrm{P}_{\text {net }}$ is highly similar to NO, for the concentration of NO was 10 times larger than HONO. And the average value of $\mathrm{P}_{\text {net }}$ is $0.26 \pm 0.08 \mathrm{ppbv} \mathrm{h}^{-1}$, leading to a cumulative HONO contribution of $3.24 \mathrm{ppbv}$. However, the measured HONO only increased $0.26 \mathrm{ppbv}$ in this period. It suggests that, (1) the reaction between $\mathrm{NO}$ and $\mathrm{OH}$ is adequate to explain 315 the $\mathrm{HONO}$ increase in the whole night, even though other sources like $\mathrm{NO}_{2}$ heterogeneous conversion might still exist; (2) except for $\mathrm{HONO}+\mathrm{OH}$, the strength of HONO sink should be at least $0.25 \mathrm{ppbv} \mathrm{h}^{-1}, 5$ times larger than that obtained by (Li et al., 2012).

We carried out sensitivity tests using one tenth, twice and half of assumed $\mathrm{OH}$ concentration $\left(1.0 \times 10^{6} \mathrm{~cm}^{-3}\right)$ (Lou et al., 320 2010). As is shown in Table S2, within the range of nighttime $\mathrm{OH}$ concentration, the cumulative production of the homogeneous reaction of $\mathrm{NO}+\mathrm{OH}$ in this study are all larger than the averaged measured accumulation of HONO, indicating that taking a value within the range of the observed nighttime $\mathrm{OH}$ concentration will not affect the conclusion of this study. 

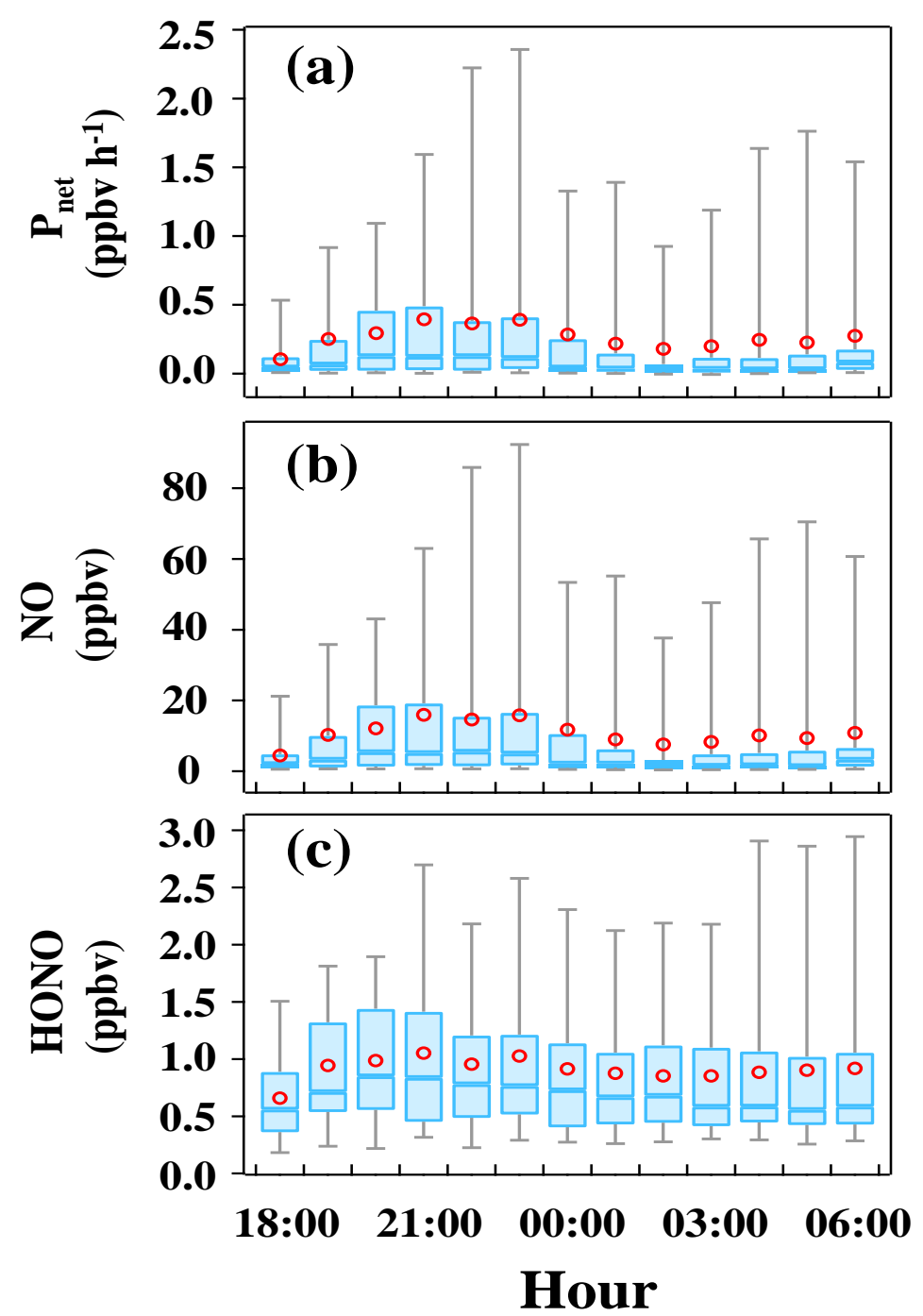

325 Figure 4. The mean nocturnal variation of $\mathbf{P}_{n e t}$, HONO and NO. The blue line in the box and red circle refer to the median and mean, respectively. Boxes represent $25 \%$ to $75 \%$ of the data, and whiskers $95 \%$ of the data.

\subsection{3 $\mathrm{NO}_{2}$ to $\mathrm{HONO}$ heterogeneous conversion}

Our analysis so far suggests that direct emissions and the homogeneous reaction between NO and $\mathrm{OH}$ are more than sufficient to explain the growth of HONO concentration through the night. The good correlation $\left(R^{2}=0.5927\right)$ between HONO and NO provides further evidence (Fig. 5 (a)). In addition, correlation analysis was conducted to explore possible pathways of heterogeneous $\mathrm{NO}_{2}$ to $\mathrm{HONO}$ conversion at night (18:00-6:00). 
The ratio of $\mathrm{HONO} / \mathrm{NO}_{2}$ has often been used to indicate the heterogeneous conversion efficiency of $\mathrm{NO}_{2}$ to $\mathrm{HONO}$ (Lammel and Cape, 1996; Stutz et al., 2002), for being less influenced by transport processes or convection. Figure 5 (c) shows a weak correlation $\left(\mathrm{R}^{2}=0.0638\right)$ between $\mathrm{HONO} / \mathrm{NO}_{2}$ and $\mathrm{PM}_{2.5}$, suggesting that the formation of $\mathrm{HONO}$ on aerosol surfaces might not be the main pathway (Kalberer et al., 1999; Kleffmann et al., 2003; Wong et al., 2011; Zhang et al., 2009; Sörgel et al., 2011a; VandenBoer et al., 2013). Because the surface area of ground (including vegetation surface, building surface and soil, etc.) is generally larger than the surface area of aerosols (Zhang et al., 2016), some studies suggested that the heterogeneous reaction of $\mathrm{NO}_{2}$ and water vapor on ground surfaces was the main source of HONO (Harrison and Kitto, 1994; Li et al., 2012;

340 Wong et al., 2012). Furthermore, the correlations between $\mathrm{HONO} / \mathrm{NO}_{2}$ and $\mathrm{NH}_{3}$ and $\mathrm{RH}$ are 0.3746 and 0.2381 , respectively, and the correlation further improved between $\mathrm{HONO} / \mathrm{NO}_{2}$ and the product of $\mathrm{NH}_{3}$ and $\mathrm{RH}\left(\mathrm{R}^{2}=0.4597\right)$. Some studies proposed that $\mathrm{NH}_{3}$ can decrease the free-energy barrier in hydrolysis of $\mathrm{NO}_{2}$ thus enhance the HONO formation (Xu et al., 2019; Li et al., 2018b; Zhang and Tao, 2010).
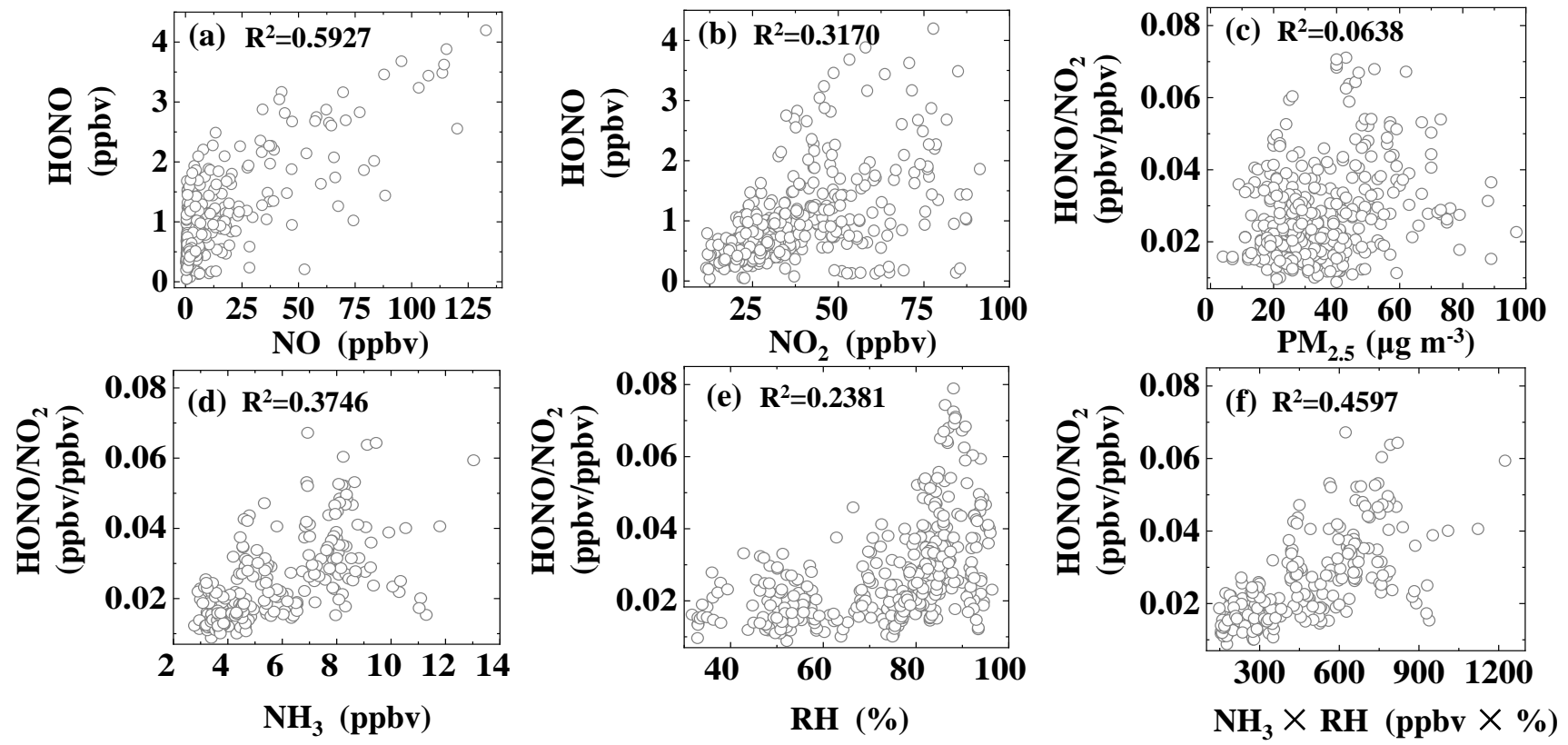

345 Figure 5. Correlations between HONO, HONO/NO 2 and various parameters during the time interval of 18:00-6:00.

In Fig. 6, we further explored the RH effect by focusing on high $\mathrm{HONO} / \mathrm{NO}_{2}$ values, i.e., the 5 highest $\mathrm{HONO} / \mathrm{NO}_{2}$ values for 5\% RH intervals (Stutz et al., 2004). When RH was lower than $87.5 \%, \mathrm{HONO} / \mathrm{NO}_{2}$ increased with RH, which is in accordance with the reaction kinetics of disproportionation reaction of $\mathrm{NO}_{2}$ and $\mathrm{H}_{2} \mathrm{O}$. Furthermore, the slope of linear fitting between $\mathrm{HONO} / \mathrm{NO}_{2}$ and $\mathrm{RH}$ was much smaller for $\mathrm{RH}$ range of $30 \% \sim 70 \%$ (slope $=0.04 \% ; \mathrm{R}^{2}=0.5202$ ) than for the $\mathrm{RH}$ range of $70 \% \sim 87.5 \%$ (slope $=0.25 \%, \mathrm{R}^{2}=0.8767$ ). Similar piecewise correlations between $\mathrm{HONO} / \mathrm{NO}_{2}$ and $\mathrm{RH}$ have been found in previous studies (Qin et al., 2009; Zhang et al., 2019b), which have been interpreted as evidence for the nonlinear dependence of $\mathrm{NO}_{2}$-to-HONO conversion efficiency on $\mathrm{RH}$. Once the relative humidity exceeded $87.5 \%$, $\mathrm{NO}_{2}$-to- 
HONO conversion appeared to be inhibited by RH (slope $=-0.32 \% ; \mathrm{R}^{2}=0.9750$ ). A possible explanation is that the number of water layers formed on various surfaces increased rapidly with $\mathrm{RH}$, resulting in effective uptake of HONO and making the

surface inaccessible or less reactive to $\mathrm{NO}_{2}$. Previous studies also found fast growth of aqueous layers when $\mathrm{RH}$ over $70 \%$ for glass (Saliba et al., 2001) and over $80 \%$ for stone (Stutz et al., 2004). The tipping point inferred from ambient observations appear to vary across locales, likely reflecting the different composition of the ground surfaces, e.g., $60 \%$ for Chengdu (Yang et al., 2021c), 65-70 \% for Beijing (Wang et al., 2017), $70 \%$ for Back Garden (Li et al., 2012), $75 \%$ for Shanghai (Wang et al., 2013), and $85 \%$ for Xi'an (Huang et al., 2017).

In sum, our correlation analysis for $\mathrm{HONO} / \mathrm{NO}_{2}$ suggests that nighttime heterogenous conversion of $\mathrm{NO}_{2}$ into $\mathrm{HONO}$ at our site might be related to $\mathrm{NH}_{3}$ and water vapor, whereas aerosol surfaces appeared unimportant.

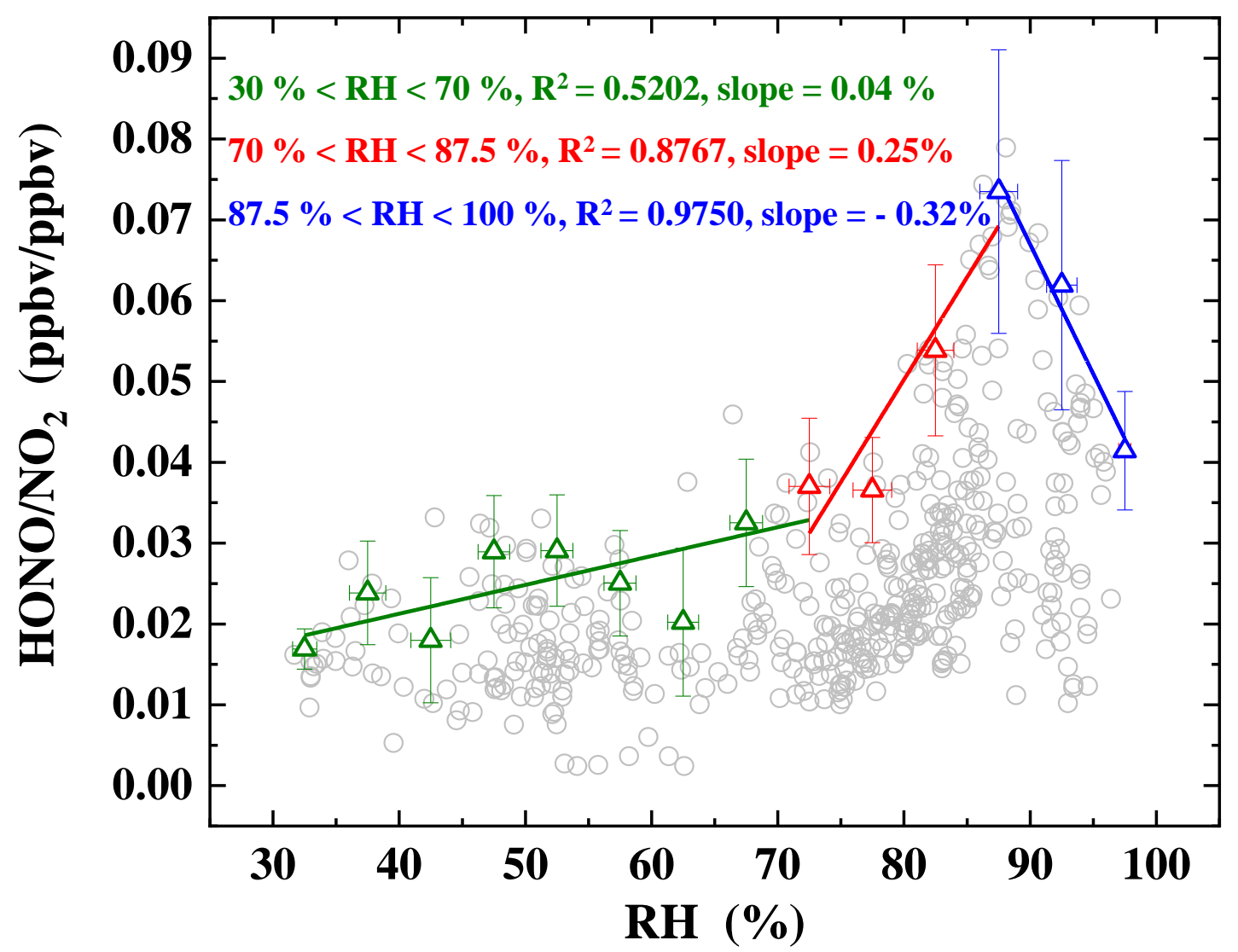

Figure 6. Scatter plot of $\mathrm{HONO} / \mathrm{NO}_{2}$ ratio against $\mathrm{RH}$ during nighttime from 18:00 to 6:00. Triangles are the average of top-5 $\mathrm{HONO} / \mathrm{NO}_{2}$ values in each $5 \% \mathrm{RH}$ interval. 


\subsubsection{Removal of HONO through dry deposition}

As discussed in Sect. 3.2.2, a sink of at least $0.25 \mathrm{ppbv} \mathrm{h}^{-1}$ is required to balance the nighttime HONO production. Since the reactions of $\mathrm{HONO}+\mathrm{OH}$ and $\mathrm{HONO}+\mathrm{HONO}$ are negligible (Kaiser and Wu, 1977; Mebel et al., 1998), it is conceivable that HONO is mainly removed through deposition on the ground. HONO dry deposition velocity $\mathrm{V}_{\mathrm{d}}$ can be estimated with

$\frac{\mathrm{d}[\mathrm{HONO}]}{\mathrm{dt}}=\mathrm{P}_{\mathrm{emis}}+\mathrm{P}_{\text {soil }}+\mathrm{P}_{\text {net }}-\frac{\mathrm{V}_{\mathrm{d}} \times[\mathrm{HONO}]}{\mathrm{H}}$

The average deposition velocity $\mathrm{V}_{\mathrm{d}}$ between 18:00-6:00 was calculated to be $2.5 \mathrm{~cm} \mathrm{~s}^{-1}$, which is within the range of prior researches (0.5-6 $\mathrm{cm} \mathrm{s}^{-1}$ ) (Harrison and Kitto, 1994; Harrison et al., 1996; Spindler et al.; Stutz et al., 2002). It should be noted that heterogeneous conversion of $\mathrm{NO}_{2}$ - $\mathrm{HONO}$ has not been taken into account, so $2.5 \mathrm{~cm} \mathrm{~s}^{-1}$ is the lower limit of dry deposition velocity. High RH at night probably increased the amount of adsorbed water on the ground surfaces and facilitates dry deposition of HONO.

\subsection{Daytime HONO budget and unknown sources analysis}

In this section, we concentrate on the daytime chemistry of HONO by a detailed budget analysis. The time variation of HONO concentration at our site can be related to its sources and sinks as follows:

$\frac{\partial[\mathrm{HONO}]}{\partial \mathrm{t}}=\mathrm{P}_{\mathrm{HONO}}-\mathrm{L}_{\mathrm{HONO}}=\left(\mathrm{P}_{\mathrm{OH}+\mathrm{NO}}+\mathrm{P}_{\text {Unknown }}+\mathrm{P}_{\mathrm{emis}}+\mathrm{P}_{\text {soil }}+\mathrm{T}_{\mathrm{V}}+\mathrm{T}_{\mathrm{H}}\right)-\left(\mathrm{L}_{\mathrm{OH}+\mathrm{HONO}}+\mathrm{L}_{\mathrm{Phot}}+\mathrm{L}_{\text {Depo }}\right)$

where $\partial \mathrm{HONO} / \partial \mathrm{t}$ represents the time variation of HONO; $\mathrm{P}_{\mathrm{HONO}}$ and $\mathrm{L}_{\mathrm{HONO}}$ are the sources and sinks of HONO, respectively;

$385 \mathrm{P}_{\mathrm{OH}+\mathrm{NO}}$ and $\mathrm{L}_{\mathrm{OH}+\mathrm{HONO}}$ are the homogeneous $\mathrm{HONO}$ formation and loss rates in Reactions R2 and R3, respectively; $\mathrm{P}_{\text {Unknown }}$ is the HONO production rate from unknown sources; $\mathrm{T}_{\mathrm{V}}$ and $\mathrm{T}_{\mathrm{H}}$ are two terms representing vertical and horizontal transport processes, respectively; LPhoto denotes the photolysis loss rate of HONO, which can be calculated with $\mathrm{L}_{\text {Photo }}=\mathrm{J}(\mathrm{HONO}) \times$ [HONO]; $\mathrm{L}_{\mathrm{dep}}$ represents the deposition loss rate of $\mathrm{HONO}$ and can be calculated as $\mathrm{L}_{\mathrm{dep}}=\mathrm{V}_{\mathrm{d}} \times[\mathrm{HONO}] / \mathrm{H}$, where $\mathrm{V}_{\mathrm{d}}$ is the deposition velocity of $\mathrm{HONO}$ and $\mathrm{H}$ is the daytime mixing height. Assuming a daytime $\mathrm{V}_{\mathrm{d}}$ of $1.6 \mathrm{~cm} \mathrm{~s}^{-1}$ (Hou et al., 2016; $\mathrm{Li}$

390 et al., 2011) and an daytime mixing height (H) of $1000 \mathrm{~m}$ (Liao et al., 2018; Song et al., 2019), the average $\mathrm{L}_{\mathrm{dep}}$ is $0.003 \pm$ $0.001 \mathrm{ppbv} \mathrm{h}^{-1}$, three orders of magnitude smaller than $\mathrm{L}_{\text {Photo }}$ and therefore can be ignored in the following discussion.

$\mathrm{OH}$ was not measured and was calculated with a parameterized approach based on strong correlation between observed $\mathrm{OH}$ radicals and $\mathrm{J}\left(\mathrm{O}^{1} \mathrm{D}\right)$. The parameterization was first proposed by (Rohrer and Berresheim, 2006) and has been applied by several studies in China (Lu et al., 2013; Lu et al., 2012; Lu et al., 2014). In this study, OH was estimated with observed $\mathrm{J}\left(\mathrm{O}^{1} \mathrm{D}\right)$ along with parameters from fitting the observed $\mathrm{OH}$ radicals and $\mathrm{J}\left(\mathrm{O}^{1} \mathrm{D}\right)$ data in Guangzhou Back Garden by (Lu et 
al., 2012). The daytime maximum $\mathrm{OH}$ concentration was estimated to be $1.3 \times 10^{7} \mathrm{~cm}^{-3}$, which is slightly smaller than the daily peak values of $1.5-2.6 \times 10^{7} \mathrm{~cm}^{-3}$ observed in summer of Guangzhou by (Lu et al., 2012). And the estimated daily average $\mathrm{OH}$ concentration is $6.7 \times 10^{6} \mathrm{~cm}^{-3}$, close to $7.5 \times 10^{6} \mathrm{~cm}^{-3}$ measured in the PRD region in autumn of 2014 by (Yang et al., 2017b). Daytime Pemis was calculated based on the method (3) (mentioned in Sect. 3.2.1). Because the HONO lifetime was in the order of 20 min under typical daytime conditions (Stutz et al., 2000) and the transport distance is only a few kilometers, the NOx emission rate extracted from the $3 \mathrm{~km} \times 3 \mathrm{~km}$ grid cell centred around sampling site is used to calculate the impact of primary emission on HONO.

405 To minimize interferences, we choose a period from 9:00 to 15:00 with intense solar radiation and a short HONO lifetime. Horizontal transport $\mathrm{T}_{\mathrm{H}}$ was assumed negligible by selecting the cases with low wind speed (Su et al., 2008b; Yang et al., 2014). The magnitude of Vertical transport $T_{V}$ can be estimated by using a parameterization for dilution by background air according to (Dillon et al., 2002), i.e. $\mathrm{T}_{\mathrm{V}}=\mathrm{k}_{\text {(dilution) }} \times$ ([HONO]-[HONO $]_{\text {background) }}$. Where $\mathrm{k}_{\text {(dilution) }}$ is the dilution rate, $[\mathrm{HONO}]_{\text {background }}$ represents the background HONO concentration. Assuming a $\mathrm{k}_{\text {(dilution) }}$ of $0.23 \mathrm{~h}^{-1}$ (Dillon et al., 2002; Sörgel et al., 2011a), a [HONO] background value of 10 pptv (Zhang et al., 2009), and taking the mean noontime [HONO] value of 400 pptv in this study, a value of about $0.09 \mathrm{ppbv} \mathrm{h}^{-1}$ can be derived, which is much smaller than $\mathrm{L}_{\text {Phot }}$ and can be ignored in the following discussion. The average daytime $\mathrm{HONO}$ emission rate from soil $\mathrm{P}_{\text {soil }}$ varied from 0.002 to 0.007 with a mean value of $0.004 \pm 0.001 \mathrm{ppbv} \mathrm{h}^{-1}$, which is three orders of magnitude smaller than Lphoto, and can also be ignored in the following discussion. As a result, $\mathrm{P}_{\text {Unknown }}$ can be expressed by Eq. (8), in which $\partial \mathrm{HONO} / \partial \mathrm{t}$ is substituted by $\Delta \mathrm{HONO} / \Delta \mathrm{dt}$.

$\frac{\Delta[\mathrm{HONO}]}{\Delta \mathrm{t}}=\left(\mathrm{P}_{\mathrm{OH}+\mathrm{NO}}+\mathrm{P}_{\mathrm{emis}}+\mathrm{P}_{\text {unknown }}\right)-\left(\mathrm{L}_{\mathrm{OH}+\mathrm{HONO}}+\mathrm{L}_{\mathrm{Phot}}\right)$

Figure 7 shows the budget of HONO from 9:00 to 15:00. As expected, photolysis HONO Lphoto $\left(1.58 \pm 0.82 \mathrm{ppbv} \mathrm{h}^{-1}\right)$ is the main loss pathway in the day, followed by a small contribution by the homogeneous reaction of $\mathrm{HONO}+\mathrm{OH}\left(\mathrm{LOH}_{\mathrm{OHONO}}\right.$,

$0.07 \pm 0.03 \mathrm{ppbv}^{-1}$ ). Among the sources, $\mathrm{P}_{\mathrm{OH}+\mathrm{NO}}$ and $\mathrm{P}_{\text {Unknown }}$ were comparable in magnitudes, with an average of $0.79 \pm$ $0.61 \mathrm{ppbv} \mathrm{h}^{-1}$ and $0.65 \pm 0.46 \mathrm{ppbv} \mathrm{h}^{-1}$, respectively. $\mathrm{P}_{\text {Unknown }}$ showed a photo-enhanced feature, reaching its maximum at 12:00 at $0.97 \mathrm{ppbv} \mathrm{h}^{-1}$, similar to the observations in Xinken (Su et al., 2008b), Beijing (Yang et al., 2014), Wangdu (Liu et al., 2019a), Changzhou (Zheng et al., 2020) and Cyprus (Meusel et al., 2016). The average of $P_{\text {Unknown }}$ is comparable to the observation in Back Garden ( $\left.0.77 \mathrm{ppbv} \mathrm{h}^{-1}\right)$ by (Li et al., 2012), but smaller than those in Xinken $\left(\approx 2.0 \mathrm{ppbv} \mathrm{h}^{-1}\right)$ by (Su et al., 2008b) and Guangzhou city area $\left(1.25 \mathrm{ppbv} \mathrm{h}^{-1}\right)$ by (Yang et al., 2017a). Homogeneous reaction of $\mathrm{NO}+\mathrm{OH}$ reached its maximum in the early morning, and contributed the most fraction in the whole day. Apparently, high NO concentrations at our site made $\mathrm{P}_{\mathrm{OH}+\mathrm{NO}}$ the biggest daytime source of $\mathrm{HONO}$, exceeding $\mathrm{P}_{\text {Unknown }}$, similar to other high-NOx sites such as Santiago de Chile (Elshorbany et al., 2009), London (Heard et al., 2004), Paris (Michoud et al., 2014), Beijing (Liu et al., 
2021; Slater et al., 2020; Zhang et al., 2019b; Liu et al., 2020c), Taiwan (Lin et al., 2006) and Hebei (Xue et al., 2020). Next,

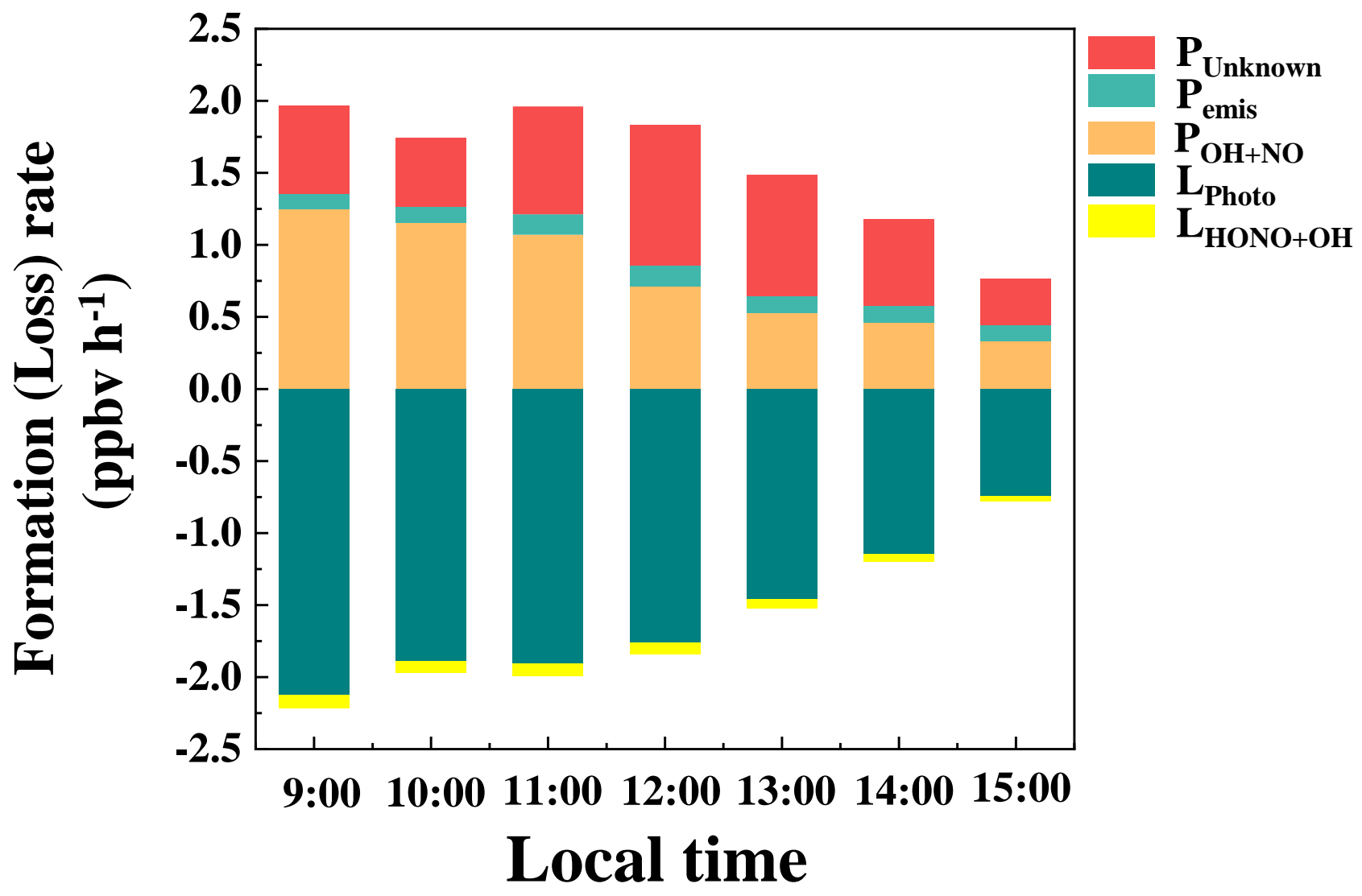

Figure 7. Items of the HONO budget (Eq. (8)) in Guangzhou during the observation period.

Figure 8 shows the correlation between $\mathrm{P}_{\text {Unknown }}$ and $\mathrm{NO}_{2}$ and $\mathrm{J}\left(\mathrm{NO}_{2}\right)$ was 0.0681 and 0.2713 , respectively. The correlation between $\mathrm{P}_{\text {Unknown }}$ and $\mathrm{NO}_{2} \times \mathrm{J}\left(\mathrm{NO}_{2}\right)$ further improved to 0.4116 , indicating that $\mathrm{P}_{\text {Unknown }}$ may be related to the photoenhanced reaction of $\mathrm{NO}_{2}$ (Jiang et al., 2020; Li et al., 2018a; Liu et al., 2019a; Liu et al., 2019b; Su et al., 2008b; Zheng et al., 2020; Huang et al., 2017).

No correlation was found between $\mathrm{P}_{\text {Unknown }}$ and $\mathrm{PM}_{2.5}\left(\mathrm{R}^{2}=0.00014\right)$, indicating that particulate matters may not be a key factor in daytime HONO production (Wong et al., 2012; Sörgel et al., 2011a; Wang et al., 2017; Zheng et al., 2020; Li et al., 2018a). Meanwhile, the correlations between $\mathrm{P}_{\text {Unknown }}$ and nitrate in $\mathrm{PM}_{1}$ and the sum of gaseous nitric acid and nitrate in $\mathrm{PM}_{1}$ were very low, with $\mathrm{R}^{2}$ of 0.0348 and 0.0062 respectively. And the correlation between $\mathrm{P}_{\text {Unknown }}$ and the product of nitrate and $\mathbf{J}\left(\mathrm{NO}_{2}\right)$ was also poor $\mathrm{R}^{2}=0.0007$, which does not relate $\mathrm{P}_{\text {Unknown }}$ to the photolysis of nitrate or gaseous nitric acid. Wang et al. (2016) and Ge et al. (2019) suggested that $\mathrm{NH}_{3}$ can efficiently promote the reaction of $\mathrm{NO}_{2}$ and $\mathrm{SO}_{2}$ to form 
HONO and sulfate. However, we did not find good correlations for $\mathrm{P}_{\text {Unknown }}$ vs. $\mathrm{NH}_{3}, \mathrm{P}_{\text {Unknown }}$ vs. $\mathrm{SO}_{2}$, or $\mathrm{P}_{\text {Unknown }}$ vs. $\mathrm{NH}_{3} \times$

In summary, at our site with relatively strong traffic impact and high $\mathrm{NO}, \mathrm{NO}+\mathrm{OH}$ appears to be the largest daytime $\mathrm{HONO}$ source followed by an unknown photolytic source, which does not seem to be related to aerosols, nor the photolysis of nitrate/nitric acid, nor the reaction between $\mathrm{NO}_{2}, \mathrm{SO}_{2}$ and $\mathrm{NH}_{3}$.
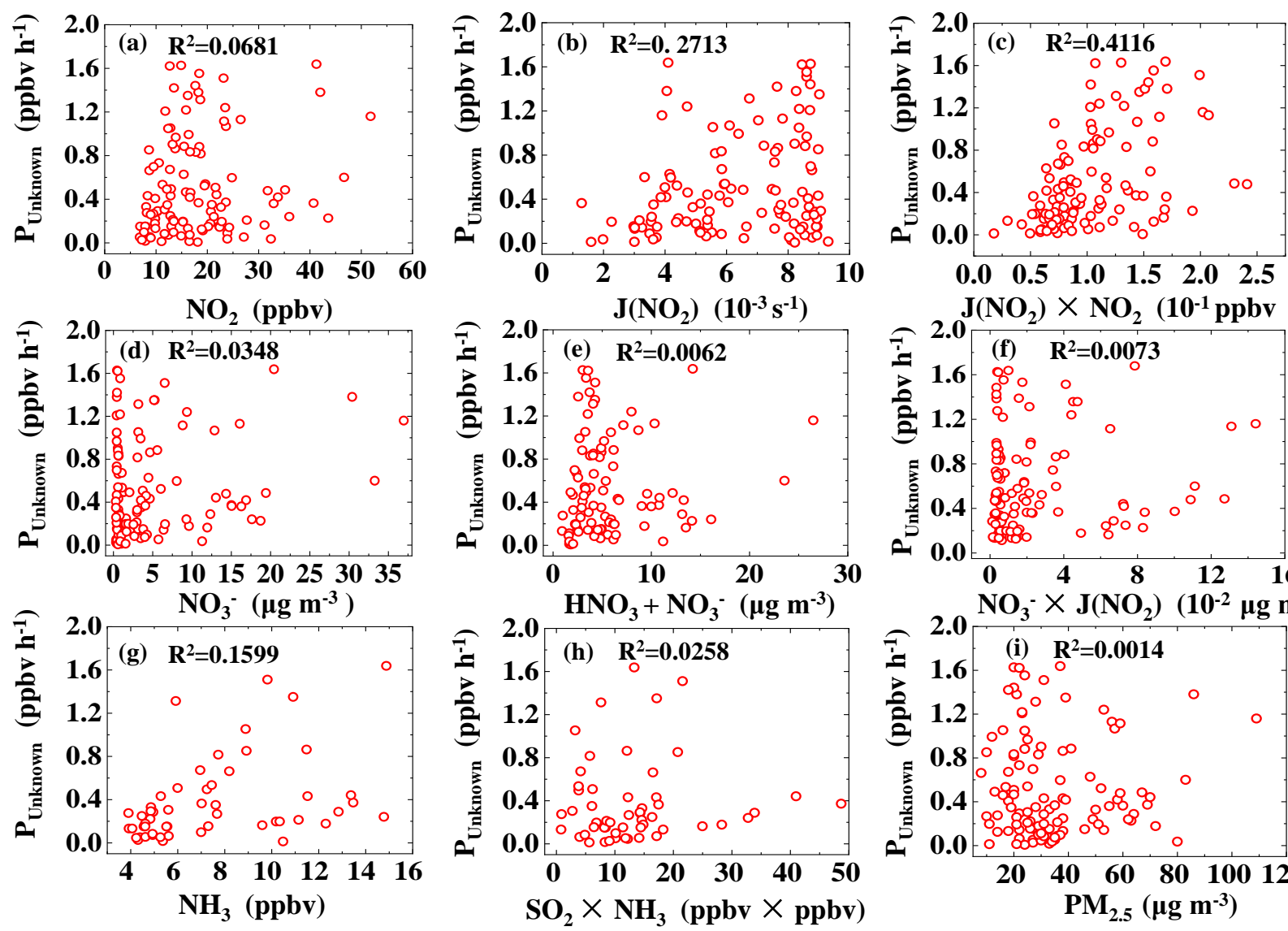
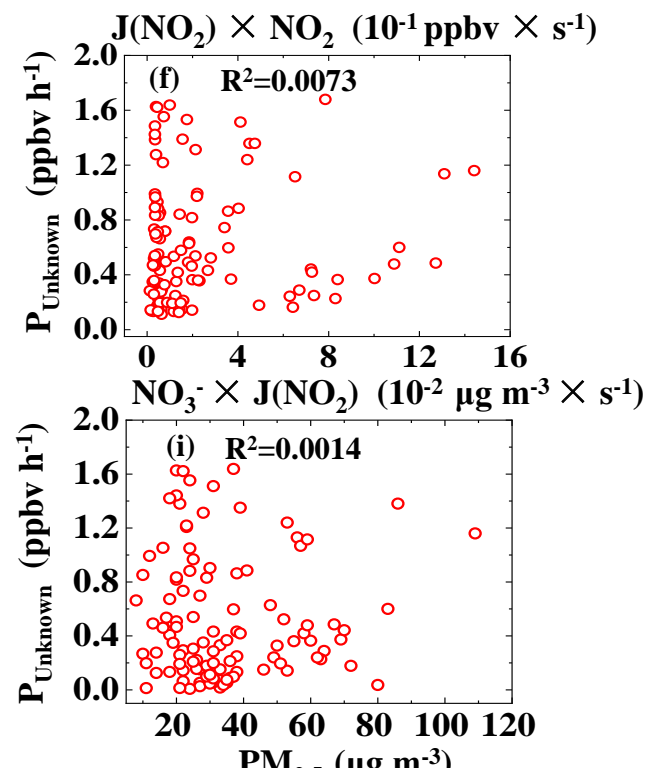

$\mathrm{PM}_{2.5}\left(\mu \mathrm{g} \mathrm{m}^{-3}\right)$

Figure 8. Correlations between daytime HONO unknown sources $P_{\text {Unknown }}$ and related parameters.

\subsection{The contribution of $\mathrm{HONO}$ and $\mathrm{O}_{3}$ to $\mathrm{OH}$}

Photolysis of $\mathrm{HONO}$ and $\mathrm{O}_{3}$ contribute dominant the primary source of $\mathrm{OH}$ radicals. Here we evaluated and compared the contribution of the two pathways. Other sources such as ozonolysis reactions of alkenes and the photolysis of peroxides, are usually not very significant in urban areas, especially during daytime, thus were not considered in this study (Li et al., 2018a). The contribution of $\mathrm{HCHO}$ photolysis to $\mathrm{OH}$ was also not considered due to the lack of measurement for HCHO. The $\mathrm{OH}$ 
radicals' production rate from $\mathrm{HONO}$ photolysis $\mathrm{P}_{\mathrm{OH}(\mathrm{HONO})}$ can be calculated from the measured photolysis frequencies and the mixing ratios of $\mathrm{HONO}$ using Eq. (9). The net $\mathrm{OH}$ radicals' production from $\mathrm{HONO} \mathrm{P}_{(\mathrm{HONO}-\mathrm{OH})}$ can be calculated by subtracting the $\mathrm{OH}$ loss caused by Reactions $\mathrm{R} 1$ and $\mathrm{R} 2$ from $\mathrm{P}_{\mathrm{OH}(\mathrm{HONO})}$ (Eq. (10)). The $\mathrm{OH}$ radicals' production rate from $\mathrm{O}_{3}$ photolysis $\mathrm{P}_{(\mathrm{O} 3-\mathrm{OH}}$ can be calculated from Eq. (11). Only part of $\mathrm{O}\left({ }^{1} \mathrm{D}\right)$ atoms, formed through the photolysis of $\mathrm{O}_{3}$ at solar radiation below $320 \mathrm{~nm}$ (Reaction $\mathrm{R} 4$ ), can generate $\mathrm{OH}$ radicals by reacting with water vapor (Reaction R5) in the atmosphere, so we used the absolute mixing ratio of water vapor, which can be derived from the temperature and relative humidity data, to calculate the fraction of $\mathrm{OH}\left(\Phi_{\mathrm{OH}}\right)$ between Reactions R5 and R6. The reaction rate of O $\left({ }^{1} \mathrm{D}\right)$ with $\mathrm{N}_{2}$ and $\mathrm{O}_{2}$ is $3.1 \times 10^{-11} \mathrm{~cm}^{3} \mathrm{~s}^{-1}$ and $4.0 \times 10^{-11} \mathrm{~cm}^{3} \mathrm{~s}^{-1}$ respectively (Seinfeld and Pandis, 2016).

$\mathrm{P}_{\mathrm{OH}(\mathrm{HONO})}=\mathrm{J}(\mathrm{HONO})[\mathrm{HONO}]$

$\mathrm{P}_{(\mathrm{HONO}-\mathrm{OH})}=\mathrm{P}_{\mathrm{OH}(\mathrm{HONO})}-\mathrm{k}_{\mathrm{NO}+\mathrm{OH}}[\mathrm{NO}][\mathrm{OH}]-\mathrm{k}_{\mathrm{HONO}+\mathrm{OH}}[\mathrm{HONO}][\mathrm{OH}]$

$\mathrm{P}_{(\mathrm{O} 3-\mathrm{OH})}=2 \Phi_{\mathrm{OH}}\left[\mathrm{O}_{3}\right] J\left(\mathrm{O}^{1} \mathrm{D}\right)$

$\Phi_{\mathrm{OH}}=\mathrm{k}_{4}\left[\mathrm{H}_{2} \mathrm{O}\right] /\left(\mathrm{k}_{4}\left[\mathrm{H}_{2} \mathrm{O}\right]+\mathrm{k}_{5}[\mathrm{M}]\right)$

$\mathrm{O}_{3}+h v \rightarrow \mathrm{O}\left({ }^{1} \mathrm{D}\right)+\mathrm{O}_{2}(\lambda<320 \mathrm{~nm})$

$\mathrm{O}\left({ }^{1} \mathrm{D}\right)+\mathrm{H}_{2} \mathrm{O} \rightarrow 2 \mathrm{OH}$

$\mathrm{O}\left({ }^{1} \mathrm{D}\right)+\mathrm{M} \rightarrow \mathrm{O}\left({ }^{3} \mathrm{P}\right)+\mathrm{M}\left(\mathrm{M}\right.$ is $\mathrm{N}_{2}$ or $\left.\mathrm{O}_{2}\right)$

475 Figure 9 shows that $\mathrm{P}_{(\mathrm{HONO}-\mathrm{OH})}$ was larger than $\mathrm{P}_{(\mathrm{O} 3-\mathrm{OH})}$ before 10:00, while the latter became always higher with the solar radiation enhanced after 10:00. Both the two sources of $\mathrm{OH}$ reached their maximum around 12:00, while $\mathrm{P}_{(\mathrm{O} 3-\mathrm{OH})}$ was approximately two times of that of $\mathrm{P}_{(\mathrm{HONO}-\mathrm{OH})}$. On average, the $\mathrm{OH}$ production rates by photolysis of $\mathrm{HONO}$ and $\mathrm{O}_{3}$ were 3.7 $\times 10^{6} \mathrm{~cm}^{-3} \mathrm{~s}^{-1}$ and $4.9 \times 10^{6} \mathrm{~cm}^{-3} \mathrm{~s}^{-1}$, respectively. Table 2 summarizes the $\mathrm{OH}$ production rate from $\mathrm{HONO}$ and $\mathrm{O}_{3}$ photolysis from previous studies worldwide. It can be seen that $\mathrm{P}_{(\mathrm{HONO}-\mathrm{OH})}$ are larger than $\mathrm{P}_{(\mathrm{O} 3-\mathrm{OH})}$ in most of the observations, but sometimes the opposite is reported. Apparently, the relative importance of $\mathrm{P}_{(\mathrm{HONO}-\mathrm{OH})}$ and $\mathrm{P}_{(\mathrm{O} 3-\mathrm{OH})}$ strongly depends on the ratio of $\mathrm{HONO} / \mathrm{O}_{3}$. Especially in winter, photolysis of $\mathrm{HONO}$ tends to be the predominant $\mathrm{OH}$ source due to the low concentration of $\mathrm{O}_{3}$ and water vapor. 


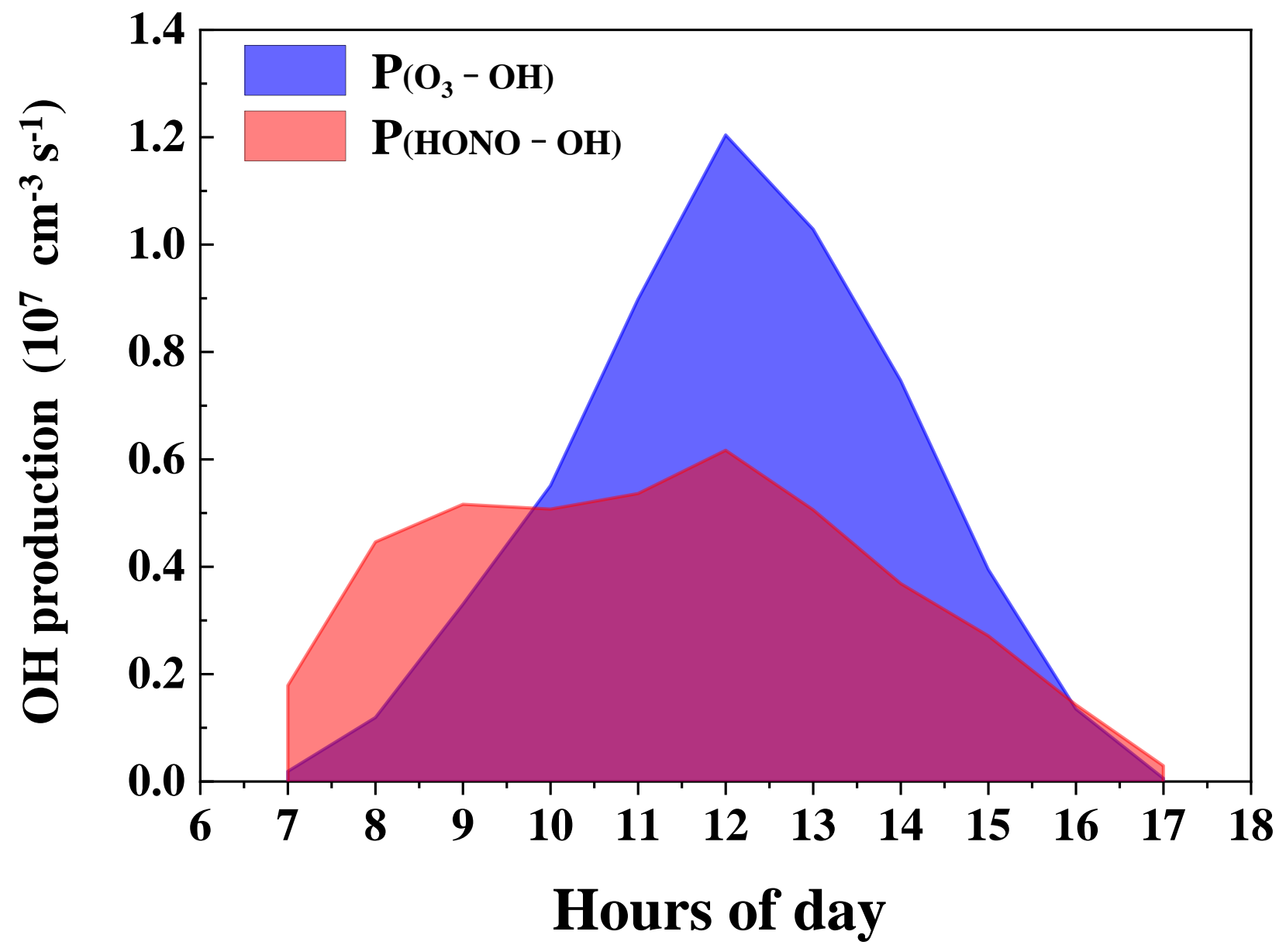

Figure 9. The yield and comparison of $\mathrm{OH}$ radicals by $\mathrm{HONO}$ and $\mathrm{O}_{3}$. 
https://doi.org/10.5194/acp-2021-178

Preprint. Discussion started: 3 May 2021

(c) Author(s) 2021. CC BY 4.0 License.

Table 2. The $\mathrm{OH}$ production rates from $\mathrm{HONO}$ and $\mathrm{O}_{3}$ photolysis in previous observations.

\begin{tabular}{|c|c|c|c|c|c|}
\hline Location & Date & Season & $\begin{array}{l}\mathrm{P}_{(\mathrm{HONO}-\mathrm{OH})} \\
\left(\mathrm{ppbv} \mathrm{h}^{-1}\right)\end{array}$ & $\begin{array}{c}\mathrm{P}_{(\mathrm{O} 3-\mathrm{OH})} \\
\left(\mathrm{ppbv} \mathrm{h}^{-1}\right)\end{array}$ & Reference \\
\hline New York, USA & Jun-Jul 1998 & Summer & 0.10 & 0.22 & 1 \\
\hline Nashville, USA & Jun-Jul 1999 & Summer & 0.29 & 0.33 & 2 \\
\hline Birmingham, UK & Jan-Feb 2000 & Winter & 0.45 & 0.01 & 3 \\
\hline New York, USA & Jun-Aug 2001 & Summer & 0.81 & 0.19 & 4 \\
\hline \multirow{2}{*}{ Santiago, Chile } & May-Jun 2005 & Winter & 2.90 & 0.01 & \multirow{2}{*}{5} \\
\hline & Mar 2005 & Summer & 1.70 & 0.13 & \\
\hline $\begin{array}{c}\text { El Arenosillo, } \\
\text { Spain }\end{array}$ & Dec 2008 & Winter & 0.11 & 0.09 & 6 \\
\hline Colorado, USA & Feb-Mar 2011 & Winter & 0.45 & 0.04 & 7 \\
\hline Beijing, China & Sep-Oct 2004 & Autumn & 1.31 & 0.18 & 8 \\
\hline Xinken, China & Oct-Nov 2004 & Autumn & 3.66 & 0.88 & 9 \\
\hline $\begin{array}{c}\text { Back Garden, } \\
\text { China }\end{array}$ & Jul 2006 & Summer & 1.32 & 2.20 & 10 \\
\hline Yufa, China & Aug 2006 & Summer & 1.68 & 0.38 & 11 \\
\hline Tung Chung, China & Aug 2011 & Summer & 1.50 & 0.90 & 12 \\
\hline Wangdu, China & June 2014 & Summer & 1.68 & 1.20 & 13 \\
\hline Hong Kong, China & Mar-May 2015 & Spring & 6.40 & $\mathrm{a}$ & 14 \\
\hline Changzhou, China & Dec 2015 & Winter & 1.04 & 0.36 & 15 \\
\hline \multirow{2}{*}{ Guangzhou, China } & Oct 2015 & Autumn & 1.24 & 0.41 & \multirow{2}{*}{16} \\
\hline & Jul 2016 & Summer & 0.71 & 0.44 & \\
\hline Ji'nan, China & Aug 2016 & Summer & 1.88 & 0.63 & 17 \\
\hline Changzhou, China & Apr 2017 & Spring & 1.66 & 2.78 & 18 \\
\hline \multirow{2}{*}{ Mount Tai, China } & Dec 2017 & Winter & 0.52 & 0.02 & \multirow{2}{*}{19} \\
\hline & Mar-Apr 2018 & Spring & 0.51 & 0.18 & \\
\hline Nanjing, China & Nov-Nov 2017/2018 & A year & 1.16 & 0.41 & 20 \\
\hline Gucheng, China & Jan-Feb 2018 & Winter & 1.40 & 0.01 & 21 \\
\hline Guangzhou, China & Sep-Nov 2018 & Autumn & 0.54 & 0.72 & 22 \\
\hline
\end{tabular}

a: far less than $\mathrm{P}_{(\mathrm{HONO}-\mathrm{OH})}$.

Reference: 1. (Zhou et al., 2002a); 2. (Martinez et al., 2003); 3. (Heard et al., 2004); 4. (Ren et al., 2003); 5. (Elshorbany et al., 2010); 6. (Sörgel et al., 2011a); 7. (Kim et al., 2014); 8. (An et al., 2009); 9. (Su et al., 2008b); 10. (Su, 2008); 11. (Yang et al., 2014); 12. 490 (Xue et al., 2016); 13. (Liu et al., 2019a); 14. (Yun et al., 2017); 15. (Zheng et al., 2020); 16. (Yang et al., 2017a); 17. (Li et al., 2018a); 18. (Shi et al., 2020a); 19. (Jiang et al., 2020); 20. (Liu et al., 2019b); 21. (Li in preparation); 22. This study 


\subsection{Box model simulation of HONO impact on atmospheric oxidation capacity}

Atmospheric oxidation capacity refers to the total removal rates of $\mathrm{CO}$ and VOCs by major oxidants (e.g., $\mathrm{OH}, \mathrm{NO}_{3}$ and $\mathrm{O}_{3}$ ) (Elshorbany et al., 2010; Xue et al., 2016; Tan et al., 2019). As the primary oxidant in the atmosphere, the OH concentration

495 is widely used to quantitatively describe the atmospheric oxidation capacity (Zheng et al., 2020; Liu et al., 2021; Shi et al., 2020b; Zhang et al., 2019a). And ozone is another indicator of atmospheric oxidation capacity. A box model (MCMv3.3.1) was conducted to simulate $\mathrm{OH}$ and $\mathrm{O}_{3}$ concentrations with and without $\mathrm{HONO}$ constrained with observational data. Figure $\mathrm{S} 4$ shows the time series of measured and simulated $\mathrm{O}_{3}$ concentrations. The model performance was evaluated to be good by the index of agreement (IOA) (see Supplementary infomation). It should be noted that the box model ignores the influence of transport and convection, so the simulated $\mathrm{O}_{3}$ concentration does not represent the actual $\mathrm{O}_{3}$ concentration in the atmosphere.

The time series of simulation results of $\mathrm{O}_{3}$ and $\mathrm{OH}$ can be found in Fig. S5. Figure 10 shows diurnal variations of simulated $\mathrm{O}_{3}$ and $\mathrm{OH}$ with and without $\mathrm{HONO}$ constrained. Daytime maximum $\mathrm{OH}$ concentration with HONO $\left(6.1 \times 10^{6} \mathrm{~cm}^{-3}\right)$ was simulated to be $59 \%$ higher than the simulation without HONO $\left(3.9 \times 10^{6} \mathrm{~cm}^{-3}\right)$, and the daily maximum concentration of $\mathrm{O}_{3}$ with HONO (43.2 ppbv) was simulated to be $68.8 \%$ higher than the simulation without HONO (25.6 ppbv). These results are both within the range of prior studies (Elshorbany et al., 2012; Fu et al., 2019; Gil et al., 2021; Liu et al., 2021; Malkin et al., 2016; Xue et al., 2020; Yang et al., 2021a; Yun et al., 2017; Zhang et al., 2016), suggesting a strong HONO enhancement effect on atmospheric oxidation capacity. In addition, the impact of $\mathrm{HONO}$ on $\mathrm{O}_{3}$ appeared two hours later than on $\mathrm{OH}$, likely reflecting that $\mathrm{HO}_{2}$ and $\mathrm{RO}_{2}$, which are key proxy radicals in $\mathrm{O}_{3}$ production were not significantly higher during early morning hours, despite higher $\mathrm{HONO}$ and $\mathrm{OH}$.
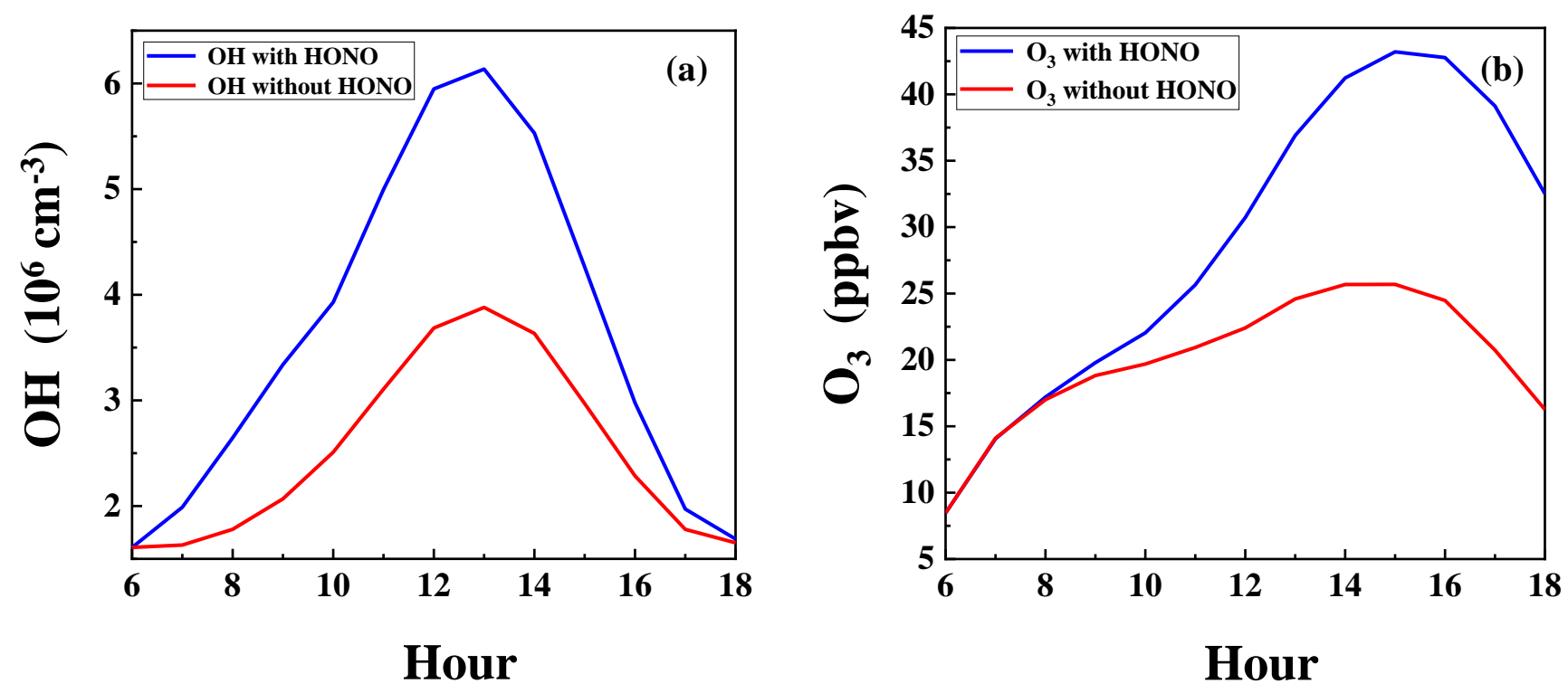
Figure 10. The diurnal variations of simulated $\mathrm{O}_{3}$ and $\mathrm{OH}$ output with and without the HONO constrained in model.

\section{Conclusions}

515 Nitrous acid (HONO) was measured with a custom-built LOPAP instrument, along with meteorological parameters and other atmospheric constituents at an urban site in Guangzhou in Pearl River Delta from 27 September to 9 November 2018. The HONO concentrations varied from 0.02 to $4.43 \mathrm{ppbv}$ with an average of $0.74 \pm 0.70 \mathrm{ppbv}$. Compared to prior measurements in Guangzhou, a decreasing trend of HONO can be seen along with improved air quality in the city over the past decade. The emission ratios (HONO/NOx) were derived from an analysis of 11 fresh plumes, varying from $0.1 \%$ to $1.5 \%$ with an average value of $0.9 \% \pm 0.4 \%$. Using this estimated emission ratio and an estimate of NOx emission rate extracted from a grid cell around our site in a high-resolution $(3 \mathrm{~km} \times 3 \mathrm{~km})$ NOx emission inventory, we estimated a primary HONO emission rate of $0.30 \pm 0.15 \mathrm{ppbv} \mathrm{h}^{-1}$, which turned out far larger (almost by an order of magnitude) than what would be estimated with a city-level NOx emission estimate, which does not adequately represent NOx emission rate specifically for the observation site. Thus, for future analysis of HONO data to properly estimate direct emission of HONO, we suggest that high quality emission data be used to reduce uncertainty. This is especially crucial for a site that receives nearby traffic emissions like ours. HONO produced by the homogeneous reaction of $\mathrm{OH}+\mathrm{NO}$ at night was $0.26 \pm 0.08 \mathrm{ppbv} \mathrm{h}^{-1}$, which can be seen as secondary results from primary emission. They were both much higher than the observed increase rate of HONO (0.02 $\left.\mathrm{ppbv} \mathrm{h}^{-1}\right)$ during the night. Nighttime soil emission rate was calculated to be $0.019 \pm 0.001 \mathrm{ppbv} \mathrm{h}^{-1}$, which is comparable to the observed increase rate of HONO during night, thus further demonstrating the importance of direct emissions. In order to balance the nighttime HONO budget and assuming dry deposition to be the principle loss process, a dry deposition rate of at least $2.5 \mathrm{~cm} \mathrm{~s}^{-1}$ is required. Correlation analysis shows that the heterogeneous reaction of $\mathrm{NO}_{2}$ related to $\mathrm{NH}_{3}$ and $\mathrm{RH}$ may contribute to the nighttime HONO formation. Daytime HONO budget analysis revealed that in order to sustain the observed HONO concentration around 450 pptv despite fast photolysis of HONO, an additional unknown source production rate $\left(\mathrm{P}_{\text {Unkonwn }}\right)$ of $0.65 \pm 0.46 \mathrm{ppbv} \mathrm{h}^{-1}$ was needed, in addition to the primary emission $\mathrm{P}_{\text {emis }}$ at $0.12 \pm 0.01$ $\mathrm{ppbv} \mathrm{h}^{-1}$, and the homogenous reaction source $\mathrm{P}_{\mathrm{OH}+\mathrm{NO}}$ at $0.79 \pm 0.61 \mathrm{ppbv} \mathrm{h}^{-1}$. It is worth noting that the homogenous HONO source by $\mathrm{NO}+\mathrm{OH}$ appeared to be a stronger source of HONO than the unknown source $\left(\mathrm{P}_{\text {Unkonwn }}\right)$, because of high levels of $\mathrm{NO}$ at our site. Correlation analysis between $\mathrm{P}_{\text {Unknown }}$ and proxies of different mechanisms showed that $\mathrm{P}_{\text {Unknown }}$ appeared to be photo-enhanced, and yet the mechanism remains unclear. Aerosols should not be as important as ground as a heterogenous reaction media, as very weak correlation between $\mathrm{P}_{\text {Unknown }}$ and $\mathrm{PM}_{2.5}$. Moreover, no correlations were found between $\mathrm{P}_{\text {Unknown }}$ and nitrate/ $\mathrm{HNO}_{3}, \mathrm{NH}_{3}, \mathrm{SO}_{2}$. We assessed the role of $\mathrm{HONO}$ in the production of $\mathrm{OH}$ and $\mathrm{O}_{3}$ by calculating $\mathrm{OH}$ production rate as well as by simulating the chemistry with a box model (MCMv3.3.1). The average net formation rate of $\mathrm{OH}$ attributed to $\mathrm{HONO}$ and $\mathrm{O}_{3}$ to was $3.7 \times 10^{6} \mathrm{~cm}^{-3} \mathrm{~s}^{-1}$ and $4.9 \times 10^{6} \mathrm{~cm}^{-3} \mathrm{~s}^{-1}$, respectively. Box model simulations confirmed strong $\mathrm{HONO}$ enhancement effect on $\mathrm{OH}$ and $\mathrm{O}_{3}$ by $59 \%$ and $68.8 \%$, respectively. 
HONO data, other trace gases data and meteorological data are available upon request from the corresponding author.

\section{Contribution}

Yihang Yu: Validation, Formal analysis, Writing - Original Draft, Visualization. Peng Cheng: Conceptualization, Methodology, Writing - Review \& Editing, Supervision, Project administration, Funding acquisition. Huirong Li:

Validation, Formal analysis, Investigation, Data Curation. Wenda Yang: Software, Investigation, Data Curation. Baobin

Han: Investigation. Wei Song: Resources. Weiwei Hu: Resources. Xinming Wang: Resources. Bin Yuan: Resources. Min Shao: Resources. Zhijiong Huang: Resources. Zhen Li: Resources. Junyu Zheng: Resources. Haichao Wang: Writing Review \& Editing. Xiaofang Yu: Investigation.

\section{Competing interests}

555 The authors declare that they have no conflict of interest.

\section{Acknowledgments}

This work was funded by the National Key Research and Development Program of China (No. 2018YFC0213904) and the Guangzhou City Science and Technology Plan Project (No. 201804010115).

\section{References}

560 Acker, K., Febo, A., Trick, S., Perrino, C., Bruno, P., Wiesen, P., Möller, D., Wieprecht, W., Auel, R., Giusto, M., Geyer, A., Platt, U., and Allegrini, I.: Nitrous acid in the urban area of Rome, Atmospheric Environment, 40, 3123-3133, https://doi.org/10.1016/j.atmosenv.2006.01.028, 2006.

Alicke, B., Platt, U., and Stutz, J.: Impact of nitrous acid photolysis on the total hydroxyl radical budget during the Limitation of Oxidant Production/Pianura Padana Produzione di Ozono study in Milan, Journal of Geophysical Research: 565 Atmospheres, 107, 8196, https://doi.org/10.1029/2000JD000075, 2002.

Alicke, B., Geyer, A., Hofzumahaus, A., Holland, F., Konrad, S., Pätz, H. W., Schäfer, J., Stutz, J., Volz-Thomas, A., and Platt, U.: OH formation by HONO photolysis during the BERLIOZ experiment, Journal of Geophysical Research: Atmospheres, 108, 8247, https://doi.org/10.1029/2001JD000579, 2003.

Amedro, D., Parker, A. E., Schoemaecker, C., and Fittschen, C.: Direct observation of OH radicals after 565nm multiphoton excitation of NO2 in the presence of H2O, Chemical Physics Letters, 513, 12-16, https://doi.org/10.1016/j.cplett.2011.07.062, 2011.

Ammann, M., Kalberer, M., Jost, D. T., Tobler, L., Rössler, E., Piguet, D., Gäggeler, H. W., and Baltensperger, U.: Heterogeneous production of nitrous acid on soot in polluted air masses, Nature, 395, 157-160, https://doi.org/10.1038/25965, 1998.

575 Ammar, R., Monge, M. E., George, C., and D'Anna, B.: Photoenhanced NO2 Loss on Simulated Urban Grime, ChemPhysChem, 11, 3956-3961, https://doi.org/10.1002/cphc.201000540, 2010. 
An, J., Zhang, W., and Qu, Y.: Impacts of a strong cold front on concentrations of HONO, HCHO, O3, and NO2 in the heavy traffic urban area of Beijing, Atmospheric Environment, 43, 3454-3459, https://doi.org/10.1016/j.atmosenv.2009.04.052, 2009.

Arens, F., Gutzwiller, L., Baltensperger, U., Gäggeler, H. W., and Ammann, M.: Heterogeneous Reaction of NO2 on Diesel Soot Particles, Environmental Science \& Technology, 35, 2191-2199, https://doi.org/10.1021/es000207s, 2001.

Aubin, D. G., and Abbatt, J. P. D.: Interaction of NO2 with Hydrocarbon Soot: Focus on HONO Yield, Surface Modification, and Mechanism, The Journal of Physical Chemistry A, 111, 6263-6273, https://doi.org/10.1021/jp068884h, 2007.

Bejan, I., Abd-el-Aal, Y., Barnes, I., Benter, T., Bohn, B., Wiesen, P., and Kleffmann, J.: The photolysis of orthonitrophenols: a new gas phase source of HONO, Phys Chem Chem Phys, 8, 2028-2035, http://dx.doi.org/10.1039/B516590C, 2006.

Brigante, M., Cazoir, D., D’Anna, B., George, C., and Donaldson, D. J.: Photoenhanced Uptake of NO2 by Pyrene Solid Films, The Journal of Physical Chemistry A, 112, 9503-9508, https://doi.org/10.1021/jp802324g, 2008.

Bröske, R., Kleffmann, J., and Wiesen, P.: Heterogeneous conversion of NO2 on secondary organic aerosol surfaces: A possible source of nitrous acid (HONO) in the atmosphere?, Atmos. Chem. Phys., 3, 469-474, https://doi.org/10.5194/acp-3469-2003, 2003.

Carr, S., Heard, D. E., and Blitz, M. A.: Comment on "Atmospheric Hydroxyl Radical Production from Electronically Excited NO2 and H2O", Science, 324, 336, https://doi.org/10.1126/science.1166669, 2009.

Cazoir, D., Brigante, M., Ammar, R., D’Anna, B., and George, C.: Heterogeneous photochemistry of gaseous NO2 on solid fluoranthene films: A source of gaseous nitrous acid (HONO) in the urban environment, Journal of Photochemistry and Photobiology A: Chemistry, 273, 23-28, https://doi.org/10.1016/j.jphotochem.2013.07.016, 2014.

Chan, C. K., and Yao, X.: Air pollution in mega cities in China, Atmospheric Environment, 42, 1-42, https://doi.org/10.1016/j.atmosenv.2007.09.003, 2008.

600 Crowley, J. N., and Carl, S. A.: OH Formation in the Photoexcitation of NO2 beyond the Dissociation Threshold in the Presence of Water Vapor, The Journal of Physical Chemistry A, 101, 4178-4184, https://doi.org/10.1021/jp970319e, 1997.

Cui, L., Li, R., Zhang, Y., Meng, Y., Fu, H., and Chen, J.: An observational study of nitrous acid (HONO) in Shanghai, China: The aerosol impact on HONO formation during the haze episodes, Science of The Total Environment, 630, 1057 1070, https://doi.org/10.1016/j.scitotenv.2018.02.063, 2018.

605 Czader, B. H., Rappenglück, B., Percell, P., Byun, D. W., Ngan, F., and Kim, S.: Modeling nitrous acid and its impact on ozone and hydroxyl radical during the Texas Air Quality Study 2006, Atmos. Chem. Phys., 12, 6939-6951, https://doi.org/10.5194/acp-12-6939-2012, 2012.

Dillon, M. B., Lamanna, M. S., Schade, G. W., Goldstein, A. H., and Cohen, R. C.: Chemical evolution of the Sacramento urban plume: Transport and oxidation, Journal of Geophysical Research: Atmospheres, 107, ACH 3-1-ACH 315, https://doi.org/10.1029/2001JD000969, 2002.

Dillon, T. J., and Crowley, J. N.: Reactive quenching of electronically excited $\mathrm{NO} 2 *$ and $\mathrm{NO} 3 *$ by $\mathrm{H} 2 \mathrm{O}$ as potential sources of atmospheric HOx radicals, Atmos. Chem. Phys., 18, 14005-14015, https://doi.org/10.5194/acp-18-14005-2018, 2018.

Elshorbany, Y. F., Kurtenbach, R., Wiesen, P., Lissi, E., Rubio, M., Villena, G., Gramsch, E., Rickard, A. R., Pilling, M. J., and Kleffmann, J.: Oxidation capacity of the city air of Santiago, Chile, Atmos. Chem. Phys., 9, 2257-2273, https://doi.org/10.5194/acp-9-2257-2009, 2009.

Elshorbany, Y. F., Kleffmann, J., Kurtenbach, R., Lissi, E., Rubio, M., Villena, G., Gramsch, E., Rickard, A. R., Pilling, M. J., and Wiesen, P.: Seasonal dependence of the oxidation capacity of the city of Santiago de Chile, Atmospheric Environment, 44, 5383-5394, https://doi.org/10.1016/j.atmosenv.2009.08.036, 2010.

620 Elshorbany, Y. F., Steil, B., Brühl, C., and Lelieveld, J.: Impact of HONO on global atmospheric chemistry calculated with an empirical parameterization in the EMAC model, Atmos. Chem. Phys., 12, 9977-10000, https://doi.org/10.5194/acp12-9977-2012, 2012.

Fan, S., Wang, B., Tesche, M., Engelmann, R., Althausen, A., Liu, J., Zhu, W., Fan, Q., Li, M., Ta, N., Song, L., and Leong, K.: Meteorological conditions and structures of atmospheric boundary layer in October 2004 over Pearl River Delta area, Atmospheric Environment, 42, 6174-6186, https://doi.org/10.1016/j.atmosenv.2008.01.067, 2008. 
Febo, A., Perrino, C., and Allegrini, I.: Measurement of nitrous acid in milan, italy, by doas and diffusion denuders, Atmospheric Environment, 30, 3599-3609, https://doi.org/10.1016/1352-2310(96)00069-6, 1996.

Finlayson-Pitts, B. J., and Pitts, J. N.: CHAPTER 4 - Photochemistry of Important Atmospheric Species, in: Chemistry of the Upper and Lower Atmosphere, edited by: Finlayson-Pitts, B. J., and Pitts, J. N., Academic Press, San Diego, 86-129, 2000.

Finlayson-Pitts, B. J., Wingen, L. M., Sumner, A. L., Syomin, D., and Ramazan, K. A.: The heterogeneous hydrolysis of NO2 in laboratory systems and in outdoor and indoor atmospheres: An integrated mechanism, Physical Chemistry Chemical Physics, 5, 223-242, https://doi.org/10.1039/B208564J, 2003.

Fu, X., Wang, T., Zhang, L., Li, Q., Wang, Z., Xia, M., Yun, H., Wang, W., Yu, C., Yue, D., Zhou, Y., Zheng, J., and Han, R.: The significant contribution of HONO to secondary pollutants during a severe winter pollution event in southern China, Atmos. Chem. Phys., 19, 1-14, https://doi.org/10.5194/acp-19-1-2019, 2019.

Ge, S., Wang, G., Zhang, S., Li, D., Xie, Y., Wu, C., Yuan, Q., Chen, J., and Zhang, H.: Abundant NH3 in China Enhances Atmospheric HONO Production by Promoting the Heterogeneous Reaction of SO2 with NO2, Environ Sci Technol, 53, 14339-14347, https://doi.org/10.1021/acs.est.9b04196, 2019.

George, C., Strekowski, R. S., Kleffmann, J., Stemmler, K., and Ammann, M.: Photoenhanced uptake of gaseous NO2 on solid organic compounds: a photochemical source of HONO?, Faraday Discuss, 130, 195-210; discussion 241-164, 519124, http://dx.doi.org/10.1039/B417888M, 2005.

Gil, J., Kim, J., Lee, M., Lee, G., Ahn, J., Lee, D. S., Jung, J., Cho, S., Whitehill, A., Szykman, J., and Lee, J.: Characteristics of HONO and its impact on O3 formation in the Seoul Metropolitan Area during the Korea-US Air Quality study, Atmospheric Environment, 247, 118182, https://doi.org/10.1016/j.atmosenv.2020.118182, 2021.

Harrison, R. M., and Kitto, A.-M. N.: Evidence for a surface source of atmospheric nitrous acid, Atmospheric Environment, 28, 1089-1094, https://doi.org/10.1016/1352-2310(94)90286-0, 1994.

Harrison, R. M., Peak, J. D., and Collins, G. M.: Tropospheric cycle of nitrous acid, Journal of Geophysical Research: Atmospheres, 101, 14429-14439, https://doi.org/10.1029/96JD00341, 1996.

Heard, D. E., Carpenter, L. J., Creasey, D. J., Hopkins, J. R., Lee, J. D., Lewis, A. C., Pilling, M. J., Seakins, P. W., Carslaw, N., and Emmerson, K. M.: High levels of the hydroxyl radical in the winter urban troposphere, Geophysical Research Letters, 31, https://doi.org/10.1029/2004GL020544, 2004.

Heland, J., Kleffmann, J., Kurtenbach, R., and Wiesen, P.: A New Instrument To Measure Gaseous Nitrous Acid (HONO) in the Atmosphere, Environmental Science \& Technology, 35, 3207-3212, https://doi.org/10.1021/es000303t, 2001.

Hendrick, F., Müller, J. F., Clémer, K., Wang, P., De Mazière, M., Fayt, C., Gielen, C., Hermans, C., Ma, J. Z., Pinardi, G., Stavrakou, T., Vlemmix, T., and Van Roozendael, M.: Four years of ground-based MAX-DOAS observations of HONO and NO2 in the Beijing area, Atmos. Chem. Phys., 14, 765-781, https://doi.org/10.5194/acp-14-765-2014, 2014.

Hofzumahaus, A., Rohrer, F., Lu, K., Bohn, B., Brauers, T., Chang, C.-C., Fuchs, H., Holland, F., Kita, K., Kondo, Y., Li, X., Lou, S., Shao, M., Zeng, L., Wahner, A., and Zhang, Y.: Amplified Trace Gas Removal in the Troposphere, Science, 324, 1702-1704, https://doi.org/10.1126/science.1164566, 2009.

Hou, S., Tong, S., Ge, M., and An, J.: Comparison of atmospheric nitrous acid during severe haze and clean periods in Beijing, China, Atmospheric Environment, 124, 199-206, https://doi.org/10.1016/j.atmosenv.2015.06.023, 2016.

Hu, M., Zhou, F., Shao, K., Zhang, Y., Tang, X., and Slanina, J.: Diurnal variations of aerosol chemical compositions and related gaseous pollutants in Beijing and Guangzhou, J Environ Sci Health A Tox Hazard Subst Environ Eng, 37, 479488, https://doi.org/10.1081/ESE-120003229, 2002.

Huang, R. J., Yang, L., Cao, J., Wang, Q., Tie, X., Ho, K. F., Shen, Z., Zhang, R., Li, G., Zhu, C., Zhang, N., Dai, W., Zhou, J., Liu, S., Chen, Y., Chen, J., and O'Dowd, C. D.: Concentration and sources of atmospheric nitrous acid (HONO) at an urban site in Western China, Science of The Total Environment, 593-594, 165-172, https://doi.org/10.1016/j.scitotenv.2017.02.166, 2017.

Huang, Z., Zhong, Z., Sha, Q., Xu, Y., Zhang, Z., Wu, L., Wang, Y., Zhang, L., Cui, X., Tang, M., Shi, B., Zheng, C., Li, Z., Hu, M., Bi, L., Zheng, J., and Yan, M.: An updated model-ready emission inventory for Guangdong Province by incorporating big data and mapping onto multiple chemical mechanisms, Science of The Total Environment, 769, 144535, https://doi.org/10.1016/j.scitotenv.2020.144535, 2021.

Indarto, A.: Heterogeneous reactions of HONO formation from NO2 and HNO3: a review, Research on Chemical Intermediates, 38, 1029-1041, https://doi.org/10.1007/s11164-011-0439-z, 2012. 
Jenkin, M. E., Saunders, S. M., Wagner, V., and Pilling, M. J.: Protocol for the development of the Master Chemical Mechanism, MCM v3 (Part B): tropospheric degradation of aromatic volatile organic compounds, Atmos. Chem. Phys., 3, 181-193, https://doi.org/10.5194/acp-3-181-2003, 2003.

Jenkin, M. E., Young, J. C., and Rickard, A. R.: The MCM v3.3.1 degradation scheme for isoprene, Atmos. Chem. Phys., 15, 11433-11459, https://doi.org/10.5194/acp-15-11433-2015, 2015.

Jeon, W., Choi, Y., Souri, A. H., Roy, A., Diao, L., Pan, S., Lee, H. W., and Lee, S. H.: Identification of chemical fingerprints in long-range transport of burning induced upper tropospheric ozone from Colorado to the North Atlantic Ocean, Science of The Total Environment, 613-614, 820-828, https://doi.org/10.1016/j.scitotenv.2017.09.177, 2018.

Jiang, Y., Xue, L., Gu, R., Jia, M., Zhang, Y., Wen, L., Zheng, P., Chen, T., Li, H., Shan, Y., Zhao, Y., Guo, Z., Bi, Y., Liu, H., Ding, A., Zhang, Q., and Wang, W.: Sources of nitrous acid (HONO) in the upper boundary layer and lower free troposphere of the North China Plain: insights from the Mount Tai Observatory, Atmos. Chem. Phys., 20, 12115-12131, https://doi.org/10.5194/acp-20-12115-2020, 2020.

Kaiser, E. W., and Wu, C. H.: A kinetic study of the gas phase formation and decomposition reactions of nitrous acid, The Journal of Physical Chemistry, 81, 1701-1706, https://doi.org/10.1021/j100533a001, 1977.

Kalberer, M., Ammann, M., Arens, F., Gäggeler, H. W., and Baltensperger, U.: Heterogeneous formation of nitrous acid (HONO) on soot aerosol particles, Journal of Geophysical Research: Atmospheres, 104, 13825-13832, https://doi.org/10.1029/1999JD900141, 1999.

Kim, S., VandenBoer, T. C., Young, C. J., Riedel, T. P., Thornton, J. A., Swarthout, B., Sive, B., Lerner, B., Gilman, J. B., Warneke, C., Roberts, J. M., Guenther, A., Wagner, N. L., Dubé, W. P., Williams, E., and Brown, S. S.: The primary and Journal of Geophysical Research: Atmospheres, 119, 6886-6896, https://doi.org/10.1002/2013JD019784, 2014.

Kirchstetter, T. W., Harley, R. A., and Littlejohn, D.: Measurement of Nitrous Acid in Motor Vehicle Exhaust, Environmental Science \& Technology, 30, 2843-2849, https://doi.org/10.1021/es960135y, 1996.

Kleffmann, J., Heland, J., Kurtenbach, R., Lrzer, J. C., and Wiesen, P.: A new instrument (LOPAP) for the detection of nitrous acid (HONO), Environmental Science and Pollution Research, 9, 48-54, 2002.

Kleffmann, J., Kurtenbach, R., Lörzer, J., Wiesen, P., Kalthoff, N., Vogel, B., and Vogel, H.: Measured and simulated vertical profiles of nitrous acid - Part I: Field measurements, Atmospheric Environment, 37, 2949-2955, https://doi.org/10.1016/S1352-2310(03)00242-5, 2003.

Kleffmann, J., Gavriloaiei, T., Hofzumahaus, A., Holland, F., Koppmann, R., Rupp, L., Schlosser, E., Siese, M., and Wahner, A.: Daytime formation of nitrous acid: A major source of $\mathrm{OH}$ radicals in a forest, Geophysical Research Letters, 32, https://doi.org/10.1029/2005GL022524, 2005.

Kleffmann, J., Lörzer, J. C., Wiesen, P., Kern, C., Trick, S., Volkamer, R., Rodenas, M., and Wirtz, K.: Intercomparison of the DOAS and LOPAP techniques for the detection of nitrous acid (HONO), Atmospheric Environment, 40, 3640-3652, https://doi.org/10.1016/j.atmosenv.2006.03.027, 2006.

710 Kramer, L. J., Crilley, L. R., Adams, T. J., Ball, S. M., Pope, F. D., and Bloss, W. J.: Nitrous acid (HONO) emissions under real-world driving conditions from vehicles in a UK road tunnel, Atmos. Chem. Phys., 20, 5231-5248, https://doi.org/10.5194/acp-20-5231-2020, 2020.

Kurtenbach, R., Becker, K. H., Gomes, J. A. G., Kleffmann, J., Lörzer, J. C., Spittler, M., Wiesen, P., Ackermann, R., Geyer, A., and Platt, U.: Investigations of emissions and heterogeneous formation of HONO in a road traffic tunnel,

715 Atmospheric Environment, 35, 3385-3394, https://doi.org/10.1016/S1352-2310(01)00138-8, 2001.

Lammel, G., and Cape, J. N.: Nitrous acid and nitrite in the atmosphere, Chemical Society Reviews, 25, 361-369, http://dx.doi.org/10.1039/CS9962500361, 1996.

Laufs, S., and Kleffmann, J.: Investigations on HONO formation from photolysis of adsorbed HNO3 on quartz glass surfaces, Phys Chem Chem Phys, 18, 9616-9625, https://doi.org/10.1039/C6CP00436A, 2016.

Laufs, S., Cazaunau, M., Stella, P., Kurtenbach, R., Cellier, P., Mellouki, A., Loubet, B., and Kleffmann, J.: Diurnal fluxes of HONO above a crop rotation, Atmos. Chem. Phys., 17, 6907-6923, https://doi.org/10.5194/acp-17-6907-2017, 2017.

Lee, J. D., Whalley, L. K., Heard, D. E., Stone, D., Dunmore, R. E., Hamilton, J. F., Young, D. E., Allan, J. D., Laufs, S., and Kleffmann, J.: Detailed budget analysis of HONO in central London reveals a missing daytime source, Atmos. Chem. Phys., 16, 2747-2764, https://doi.org/10.5194/acp-16-2747-2016, 2016. 
Lelieveld, J., Gromov, S., Pozzer, A., and Taraborrelli, D.: Global tropospheric hydroxyl distribution, budget and reactivity, Atmos. Chem. Phys., 16, 12477-12493, https://doi.org/10.5194/acp-16-12477-2016, 2016.

Li, D., Xue, L., Wen, L., Wang, X., Chen, T., Mellouki, A., Chen, J., and Wang, W.: Characteristics and sources of nitrous acid in an urban atmosphere of northern China: Results from 1-yr continuous observations, Atmospheric Environment, 182, 296-306, https://doi.org/10.1016/j.atmosenv.2018.03.033, 2018a.

Li, G., Lei, W., Zavala, M., Volkamer, R., Dusanter, S., Stevens, P., and Molina, L. T.: Impacts of HONO sources on the photochemistry in Mexico City during the MCMA-2006/MILAGO Campaign, Atmos. Chem. Phys., 10, 6551-6567, https://doi.org/10.5194/acp-10-6551-2010, 2010.

Li, H., Cheng, P., Yu, Y., and Yang, W.: Nitrous acid (HONO) budget analysis at a rural site in the North China Plain during snowy days, in preparation.

Li, J., Lu, K., Lv, W., Li, J., Zhong, L., Ou, Y., Chen, D., Huang, X., and Zhang, Y.: Fast increasing of surface ozone concentrations in Pearl River Delta characterized by a regional air quality monitoring network during 2006-2011, Journal of Environmental Sciences, 26, 23-36, https://doi.org/10.1016/S1001-0742(13)60377-0, 2014a.

Li, L., Duan, Z., Li, H., Zhu, C., Henkelman, G., Francisco, J. S., and Zeng, X. C.: Formation of HONO from the NH3 promoted hydrolysis of NO2 dimers in the atmosphere, Proceedings of the National Academy of Sciences, 115, 7236-7241, https://doi.org/10.1073/pnas.1807719115, 2018b.

Li, S., Matthews, J., and Sinha, A.: Atmospheric hydroxyl radical production from electronically excited NO2 and $\mathrm{H} 2 \mathrm{O}$, Science, 319, 1657-1660, https://doi.org/10.1126/science.1151443, 2008.

Li, X., Brauers, T., Häseler, R., Bohn, B., Fuchs, H., Hofzumahaus, A., Holland, F., Lou, S., Lu, K. D., Rohrer, F., Hu, M., Zeng, L. M., Zhang, Y. H., Garland, R. M., Su, H., Nowak, A., Wiedensohler, A., Takegawa, N., Shao, M., and Wahner, A.: Exploring the atmospheric chemistry of nitrous acid (HONO) at a rural site in Southern China, Atmos. Chem. Phys., 12, 1497-1513, https://doi.org/10.5194/acp-12-1497-2012, 2012.

Li, X., Rohrer, F., Hofzumahaus, A., Brauers, T., Häseler, R., Bohn, B., Broch, S., Fuchs, H., Gomm, S., Holland, F., Jäger, J., Kaiser, J., Keutsch, F. N., Lohse, I., Lu, K., Tillmann, R., Wegener, R., Wolfe, G. M., Mentel, T. F., Kiendler-Scharr, A., and Wahner, A.: Missing Gas-Phase Source of HONO Inferred from Zeppelin Measurements in the Troposphere, Science, 344, 292-296, https://doi.org/10.1126/science.1248999, 2014b.

Li, Y., An, J., Min, M., Zhang, W., Wang, F., and Xie, P.: Impacts of HONO sources on the air quality in Beijing, Tianjin and Hebei Province of China, Atmospheric Environment, 45, 4735-4744, https://doi.org/10.1016/j.atmosenv.2011.04.086, 2011.

Liao, B., Huang, J., Wang, C., Weng, J., Li, L., Cai, H., and D, W.: Comparative analysis on the boundary layer features of haze processes and cleaning process in Guangzhou, China Environmental Science, 38, 4432-4443, DOI:10.19674/j.cnki.issn1000-6923.2018.0496, 2018.

Liao, W., Wu, L., Zhou, S., Wang, X., and Chen, D.: Impact of Synoptic Weather Types on Ground-Level Ozone Concentrations in Guangzhou, China, Asia-Pacific Journal of Atmospheric Sciences, https://doi.org/10.1007/s13143-02000186-2, 2020.

Lin, Y.-C., Cheng, M.-T., Ting, W.-Y., and Yeh, C.-R.: Characteristics of gaseous HNO2, HNO3, NH3 and particulate ammonium nitrate in an urban city of Central Taiwan, Atmospheric Environment, 40, 4725-4733, https://doi.org/10.1016/j.atmosenv.2006.04.037, 2006.

Liu, J., Deng, H., Li, S., Jiang, H., Mekic, M., Zhou, W., Wang, Y., Loisel, G., Wang, X., and Gligorovski, S.: LightEnhanced Heterogeneous Conversion of NO2 to HONO on Solid Films Consisting of Fluorene and Fluorene/Na2SO4: An Impact on Urban and Indoor Atmosphere, Environ Sci Technol, 54, 11079-11086, https://doi.org/10.1021/acs.est.0c02627, 2020a.

Liu, J., Liu, Z., Ma, Z., Yang, S., Yao, D., Zhao, S., Hu, B., Tang, G., Sun, J., Cheng, M., Xu, Z., and Wang, Y.: Detailed budget analysis of HONO in Beijing, China: Implication on atmosphere oxidation capacity in polluted megacity, Atmospheric Environment, 244, 117957, https://doi.org/10.1016/j.atmosenv.2020.117957, 2021.

Liu, Y.: Observations and parameterized modelling of ambient nitrous acid (HONO) in the megacity areas of the eastern China, Ph.D. thsis. College of Environmental Sciences and Engineering, Peking University, China, 2017.

Liu, Y., Lu, K., Li, X., Dong, H., Tan, Z., Wang, H., Zou, Q., Wu, Y., Zeng, L., Hu, M., Min, K. E., Kecorius, S., Wiedensohler, A., and Zhang, Y.: A Comprehensive Model Test of the HONO Sources Constrained to Field Measurements at Rural North China Plain, Environ Sci Technol, https://doi.org/10.1021/acs.est.8b06367, 2019a. 
Liu, Y., Nie, W., Xu, Z., Wang, T., Wang, R., Li, Y., Wang, L., Chi, X., and Ding, A.: Semi-quantitative understanding of source contribution to nitrous acid (HONO) based on 1 year of continuous observation at the SORPES station in eastern China, Atmos. Chem. Phys., 19, 13289-13308, https://doi.org/10.5194/acp-19-13289-2019, $2019 \mathrm{~b}$.

Liu, Y., Ni, S., Jiang, T., Xing, S., Zhang, Y., Bao, X., Feng, Z., Fan, X., Zhang, L., and Feng, H.: Influence of Chinese New Year overlapping COVID-19 lockdown on HONO sources in Shijiazhuang, Science of The Total Environment, 745, 141025, https://doi.org/10.1016/j.scitotenv.2020.141025, 2020b.

Liu, Y., Zhang, Y., Lian, C., Yan, C., Feng, Z., Zheng, F., Fan, X., Chen, Y., Wang, W., Chu, B., Wang, Y., Cai, J., Du, W., Daellenbach, K. R., Kangasluoma, J., Bianchi, F., Kujansuu, J., Petäjä, T., Wang, X., Hu, B., Wang, Y., Ge, M., He, H., and Kulmala, M.: The promotion effect of nitrous acid on aerosol formation in wintertime in Beijing: the possible contribution of traffic-related emissions, Atmos. Chem. Phys., 20, 13023-13040, https://doi.org/10.5194/acp-20-13023-2020, 2020c.

Lou, S., Holland, F., Rohrer, F., Lu, K., Bohn, B., Brauers, T., Chang, C. C., Fuchs, H., Häseler, R., Kita, K., Kondo, Y., Li, X., Shao, M., Zeng, L., Wahner, A., Zhang, Y., Wang, W., and Hofzumahaus, A.: Atmospheric OH reactivities in the Pearl River Delta - China in summer 2006: measurement and model results, Atmos. Chem. Phys., 10, 11243-11260, https://doi.org/10.5194/acp-10-11243-2010, 2010.

Lu, K. D., Rohrer, F., Holland, F., Fuchs, H., Bohn, B., Brauers, T., Chang, C. C., Häseler, R., Hu, M., Kita, K., Kondo, Y., Li, X., Lou, S. R., Nehr, S., Shao, M., Zeng, L. M., Wahner, A., Zhang, Y. H., and Hofzumahaus, A.: Observation and modelling of OH and HO2 concentrations in the Pearl River Delta 2006: a missing OH source in a VOC rich atmosphere, Atmos. Chem. Phys., 12, 1541-1569, https://doi.org/10.5194/acp-12-1541-2012, 2012.

795 Lu, K. D., Hofzumahaus, A., Holland, F., Bohn, B., Brauers, T., Fuchs, H., Hu, M., Häseler, R., Kita, K., Kondo, Y., Li, X., Lou, S. R., Oebel, A., Shao, M., Zeng, L. M., Wahner, A., Zhu, T., Zhang, Y. H., and Rohrer, F.: Missing OH source in a suburban environment near Beijing: observed and modelled OH and HO2 concentrations in summer 2006, Atmos. Chem. Phys., 13, 1057-1080, https://doi.org/10.5194/acp-13-1057-2013, 2013.

Lu, K. D., Rohrer, F., Holland, F., Fuchs, H., Brauers, T., Oebel, A., Dlugi, R., Hu, M., Li, X., Lou, S. R., Shao, M., Zhu, T., Wahner, A., Zhang, Y. H., and Hofzumahaus, A.: Nighttime observation and chemistry of HOx in the Pearl River Delta and Beijing in summer 2006, Atmos. Chem. Phys., 14, 4979-4999, https://doi.org/10.5194/acp-14-4979-2014, 2014.

Lu, X., Hong, J., Zhang, L., Cooper, O. R., Schultz, M. G., Xu, X., Wang, T., Gao, M., Zhao, Y., and Zhang, Y.: Severe Surface Ozone Pollution in China: A Global Perspective, Environmental Science \& Technology Letters, 5, 487-494, https://doi.org/10.1021/acs.estlett.8b00366, 2018.

Maljanen, M., Yli-Pirilä, P., Hytönen, J., Joutsensaari, J., and Martikainen, P. J.: Acidic northern soils as sources of atmospheric nitrous acid (HONO), Soil Biology and Biochemistry, 67, 94-97, https://doi.org/10.1016/j.soilbio.2013.08.013, 2013.

Malkin, T. L., Heard, D. E., Hood, C., Stocker, J., Carruthers, D., MacKenzie, I. A., Doherty, R. M., Vieno, M., Lee, J., Kleffmann, J., Laufs, S., and Whalley, L. K.: Assessing chemistry schemes and constraints in air quality models used to predict ozone in London against the detailed Master Chemical Mechanism, Faraday Discuss, 189, 589-616, https://doi.org/10.1039/C5FD00218D, 2016.

Martinez, M., Harder, H., Kovacs, T. A., Simpas, J. B., Bassis, J., Lesher, R., Brune, W. H., Frost, G. J., Williams, E. J., Stroud, C. A., Jobson, B. T., Roberts, J. M., Hall, S. R., Shetter, R. E., Wert, B., Fried, A., Alicke, B., Stutz, J., Young, V. L., White, A. B., and Zamora, R. J.: $\mathrm{OH}$ and $\mathrm{HO} 2$ concentrations, sources, and loss rates during the Southern Oxidants Study in

815 Nashville, Tennessee, summer 1999, Journal of Geophysical Research: Atmospheres, 108, https://doi.org/10.1029/2003JD003551, 2003.

Mebel, A. M., Lin, M. C., and Melius, C. F.: Rate Constant of the HONO + HONO $\rightarrow \mathrm{H} 2 \mathrm{O}+\mathrm{NO}+\mathrm{NO} 2$ Reaction from ab Initio MO and TST Calculations, The Journal of Physical Chemistry A, 102, 1803-1807, https://doi.org/10.1021/jp973449w, 1998.

Meng, F., Qin, M., Tang, K., Duan, J., Fang, W., Liang, S., Ye, K., Xie, P., Sun, Y., Xie, C., Ye, C., Fu, P., Liu, J., and Liu, W.: High-resolution vertical distribution and sources of $\mathrm{HONO}$ and $\mathrm{NO} 2$ in the nocturnal boundary layer in urban Beijing, China, Atmos. Chem. Phys., 20, 5071-5092, https://doi.org/10.5194/acp-20-5071-2020, 2020.

Meusel, H., Kuhn, U., Reiffs, A., Mallik, C., Harder, H., Martinez, M., Schuladen, J., Bohn, B., Parchatka, U., Crowley, J. N., Fischer, H., Tomsche, L., Novelli, A., Hoffmann, T., Janssen, R. H. H., Hartogensis, O., Pikridas, M., Vrekoussis, M., Bourtsoukidis, E., Weber, B., Lelieveld, J., Williams, J., Pöschl, U., Cheng, Y., and Su, H.: Daytime formation of nitrous acid 
at a coastal remote site in Cyprus indicating a common ground source of atmospheric HONO and NO, Atmos. Chem. Phys., 16, 14475-14493, https://doi.org/10.5194/acp-16-14475-2016, 2016.

Meusel, H., Tamm, A., Kuhn, U., Wu, D., Leifke, A. L., Fiedler, S., Ruckteschler, N., Yordanova, P., Lang-Yona, N., Pöhlker, M., Lelieveld, J., Hoffmann, T., Pöschl, U., Su, H., Weber, B., and Cheng, Y.: Emission of nitrous acid from soil and biological soil crusts represents an important source of HONO in the remote atmosphere in Cyprus, Atmos. Chem. Phys., 18, 799-813, https://doi.org/10.5194/acp-18-799-2018, 2018.

Michoud, V., Kukui, A., Camredon, M., Colomb, A., Borbon, A., Miet, K., Aumont, B., Beekmann, M., DurandJolibois, R., Perrier, S., Zapf, P., Siour, G., Ait-Helal, W., Locoge, N., Sauvage, S., Afif, C., Gros, V., Furger, M., Ancellet, G., and Doussin, J. F.: Radical budget analysis in a suburban European site during the MEGAPOLI summer field campaign, Atmos. Chem. Phys., 12, 11951-11974, https://doi.org/10.5194/acp-12-11951-2012, 2012.

Michoud, V., Colomb, A., Borbon, A., Miet, K., Beekmann, M., Camredon, M., Aumont, B., Perrier, S., Zapf, P., Siour, G., Ait-Helal, W., Afif, C., Kukui, A., Furger, M., Dupont, J. C., Haeffelin, M., and Doussin, J. F.: Study of the unknown HONO daytime source at a European suburban site during the MEGAPOLI summer and winter field campaigns, Atmos. Chem. Phys., 14, 2805-2822, https://doi.org/10.5194/acp-14-2805-2014, 2014.

Ndour, M., D'Anna, B., George, C., Ka, O., Balkanski, Y., Kleffmann, J., Stemmler, K., and Ammann, M.: Photoenhanced uptake of NO2 on mineral dust: Laboratory experiments and model simulations, Geophysical Research Letters, 35, https://doi.org/10.1029/2007GL032006, 2008.

Neuman, J. A., Trainer, M., Brown, S. S., Min, K.-E., Nowak, J. B., Parrish, D. D., Peischl, J., Pollack, I. B., Roberts, J. M., Ryerson, T. B., and Veres, P. R.: HONO emission and production determined from airborne measurements over the

845 Southeast U.S, Journal of Geophysical Research: Atmospheres, 121, 9237-9250, https://doi.org/10.1002/2016JD025197, 2016.

Nie, W., Ding, A. J., Xie, Y. N., Xu, Z., Mao, H., Kerminen, V. M., Zheng, L. F., Qi, X. M., Huang, X., Yang, X. Q., Sun, J. N., Herrmann, E., Petäjä, T., Kulmala, M., and Fu, C. B.: Influence of biomass burning plumes on HONO chemistry in eastern China, Atmos. Chem. Phys., 15, 1147-1159, https://doi.org/10.5194/acp-15-1147-2015, 2015.

Oswald, R., Behrendt, T., Ermel, M., Wu, D., Su, H., Cheng, Y., Breuninger, C., Moravek, A., Mougin, E., Delon, C., Loubet, B., Pommerening-Röser, A., Sörgel, M., Pöschl, U., Hoffmann, T., Andreae, M. O., Meixner, F. X., and Trebs, I.: HONO Emissions from Soil Bacteria as a Major Source of Atmospheric Reactive Nitrogen, Science, 341, 1233-1235, https://doi.org/10.1126/science.1242266, 2013.

Pagsberg, P., Bjergbakke, E., Ratajczak, E., and Sillesen, A.: Kinetics of the gas phase reaction OH + $\mathrm{NO}(+\mathrm{M}) \rightarrow \mathrm{HONO}(+\mathrm{M})$ and the determination of the UV absorption cross sections of HONO, Chemical Physics Letters, 272, 383-390, https://doi.org/10.1016/S0009-2614(97)00576-9, 1997.

Porada, P., Tamm, A., Raggio, J., Cheng, Y., Kleidon, A., Pöschl, U., and Weber, B.: Global NO and HONO emissions of biological soil crusts estimated by a process-based non-vascular vegetation model, Biogeosciences, 16, 2003-2031, https://doi.org/10.5194/bg-16-2003-2019, 2019.

860 Qin, M., Xie, P., Su, H., Gu, J., Peng, F., Li, S., Zeng, L., Liu, J., Liu, W., and Zhang, Y.: An observational study of the HONO-NO2 coupling at an urban site in Guangzhou City, South China, Atmospheric Environment, 43, 5731-5742, https://doi.org/10.1016/j.atmosenv.2009.08.017, 2009.

Ren, X., Harder, H., Martinez, M., Lesher, R. L., Oliger, A., Simpas, J. B., Brune, W. H., Schwab, J. J., Demerjian, K. L., He, Y., Zhou, X., and Gao, H.: OH and HO2 Chemistry in the urban atmosphere of New York City, Atmospheric Environment, 37, 3639-3651, https://doi.org/10.1016/S1352-2310(03)00459-X, 2003.

Rohrer, F., and Berresheim, H.: Strong correlation between levels of tropospheric hydroxyl radicals and solar ultraviolet radiation, Nature, 442, 184-187, https://doi.org/10.1038/nature04924, 2006.

Saliba, N. A., Yang, H., and Finlayson-Pitts, B. J.: Reaction of Gaseous Nitric Oxide with Nitric Acid on Silica Surfaces in the Presence of Water at Room Temperature, The Journal of Physical Chemistry A, 105, 10339-10346, https://doi.org/10.1021/jp012330r, 2001.

Sarwar, G., Roselle, S. J., Mathur, R., Appel, W., Dennis, R. L., and Vogel, B.: A comparison of CMAQ HONO predictions with observations from the Northeast Oxidant and Particle Study, Atmospheric Environment, 42, 5760-5770, https://doi.org/10.1016/j.atmosenv.2007.12.065, 2008. 
Saunders, S. M., Jenkin, M. E., Derwent, R. G., and Pilling, M. J.: Protocol for the development of the Master Chemical Mechanism, MCM v3 (Part A): tropospheric degradation of non-aromatic volatile organic compounds, Atmos. Chem. Phys., 3, 161-180, https://doi.org/10.5194/acp-3-161-2003, 2003.

Seinfeld, J. H., and Pandis, S. N.: Atmospheric chemistry and physics: from air pollution to climate change, John Wiley \& Sons, 2016.

Shi, X., Ge, Y., Zhang, Y., Ma, Y., and Zheng, J.: HONO observation and assessment of the effects of atmospheric oxidation capacity in Changzhou during the springtime of 2017, Environmental Science, v.41, 113-121, DOI: 10. 13227/j. hjkx. 201909032, 2020a.

Shi, X., Ge, Y., Zheng, J., Ma, Y., Ren, X., and Zhang, Y.: Budget of nitrous acid and its impacts on atmospheric oxidative capacity at an urban site in the central Yangtze River Delta region of China, Atmospheric Environment, 238, 117725, https://doi.org/10.1016/j.atmosenv.2020.117725, 2020b.

Slater, E. J., Whalley, L. K., Woodward-Massey, R., Ye, C., Lee, J. D., Squires, F., Hopkins, J. R., Dunmore, R. E., Shaw, M., Hamilton, J. F., Lewis, A. C., Crilley, L. R., Kramer, L., Bloss, W., Vu, T., Sun, Y., Xu, W., Yue, S., Ren, L., Acton, W. J. F., Hewitt, C. N., Wang, X., Fu, P., and Heard, D. E.: Elevated levels of $\mathrm{OH}$ observed in haze events during wintertime in central Beijing, Atmos. Chem. Phys., 20, 14847-14871, https://doi.org/10.5194/acp-20-14847-2020, 2020.

Song, L., Deng, T., and Wu, D.: Study on planetary boundary layer height in a typical haze period and different weather types over Guangzhou, Acta Scientiae Circumstantiae, 39(5), 1381-1391, DOI: 10.13671/j.hjkxxb.2019.0080, 2019.

Sörgel, M., Regelin, E., Bozem, H., Diesch, J. M., Drewnick, F., Fischer, H., Harder, H., Held, A., Hosaynali-Beygi, Z., Martinez, M., and Zetzsch, C.: Quantification of the unknown HONO daytime source and its relation to NO2, Atmos. Chem. Phys., 11, 10433-10447, https://doi.org/10.5194/acp-11-10433-2011, 2011 a.

Sörgel, M., Trebs, I., Serafimovich, A., Moravek, A., Held, A., and Zetzsch, C.: Simultaneous HONO measurements in and above a forest canopy: influence of turbulent exchange on mixing ratio differences, Atmos. Chem. Phys., 11, 841-855, https://doi.org/10.5194/acp-11-841-2011, 2011b.

Sosedova, Y., Rouvière, A., Bartels-Rausch, T., and Ammann, M.: UVA/Vis-induced nitrous acid formation on polyphenolic films exposed to gaseous NO2, Photochemical \& Photobiological Sciences, 10, 1680-1690, http://dx.doi.org/10.1039/C1PP05113J, 2011.

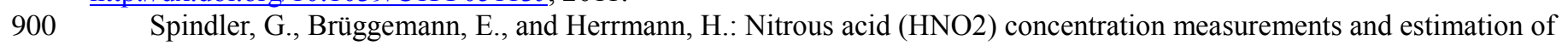
dry deposition over grassland in eastern Germany, Proceedings of the EUROTRAC Symposium 1998, Vol. 2, WITpress, Southampton, UK, 218-222,1999.

Stemmler, K., Ammann, M., Donders, C., Kleffmann, J., and George, C.: Photosensitized reduction of nitrogen dioxide on humic acid as a source of nitrous acid, Nature, 440, 195-198, https://doi.org/10.1038/nature04603, 2006.

Stutz, J., Kim, E. S., Platt, U., Bruno, P., Perrino, C., and Febo, A.: UV-visible absorption cross sections of nitrous acid, Journal of Geophysical Research: Atmospheres, 105, 14585-14592, https://doi.org/10.1029/2000JD900003, 2000.

Stutz, J., Alicke, B., and Neftel, A.: Nitrous acid formation in the urban atmosphere: Gradient measurements of NO2 and HONO over grass in Milan, Italy, Journal of Geophysical Research: Atmospheres, 107, 8192, https://doi.org/10.1029/2001JD000390, 2002.

Stutz, J., Alicke, B., Ackermann, R., Geyer, A., Wang, S., White, A. B., Williams, E. J., Spicer, C. W., and Fast, J. D.: Relative humidity dependence of HONO chemistry in urban areas, Journal of Geophysical Research: Atmospheres, 109, https://doi.org/10.1029/2003JD004135, 2004.

$\mathrm{Su}, \mathrm{H}$.: HONO: a study to its sources and impacts from field measurements at the sub-urban areas of PRD region, Ph.D. thsis, College of Environmental Sciences and Engineering, Peking University, China, 2008.

Su, H., Cheng, Y. F., Cheng, P., Zhang, Y. H., Dong, S., Zeng, L. M., Wang, X., Slanina, J., Shao, M., and Wiedensohler, A.: Observation of nighttime nitrous acid (HONO) formation at a non-urban site during PRIDE-PRD2004 in China, Atmospheric Environment, 42, 6219-6232, https://doi.org/10.1016/j.atmosenv.2008.04.006, 2008a.

Su, H., Cheng, Y. F., Shao, M., Gao, D. F., Yu, Z. Y., Zeng, L. M., Slanina, J., Zhang, Y. H., and Wiedensohler, A.: Nitrous acid (HONO) and its daytime sources at a rural site during the 2004 PRIDE-PRD experiment in China, Journal of Geophysical Research, 113, https://doi.org/10.1029/2007JD009060, 2008b.

Su, H., Cheng, Y., Oswald, R., Behrendt, T., Trebs, I., Meixner, F. X., Andreae, M. O., Cheng, P., Zhang, Y., and Pöschl, U.: Soil Nitrite as a Source of Atmospheric HONO and OH Radicals, Science, 333, 1616-1618, https://doi.org/10.1126/science.1207687, 2011. 
Tan, Z., Fuchs, H., Lu, K., Hofzumahaus, A., Bohn, B., Broch, S., Dong, H., Gomm, S., Häseler, R., He, L., Holland, F., Li, X., Liu, Y., Lu, S., Rohrer, F., Shao, M., Wang, B., Wang, M., Wu, Y., Zeng, L., Zhang, Y., Wahner, A., and Zhang, Y.: Radical chemistry at a rural site (Wangdu) in the North China Plain: observation and model calculations of OH, $\mathrm{HO} 2$ and RO2 radicals, Atmos. Chem. Phys., 17, 663-690, https://doi.org/10.5194/acp-17-663-2017, 2017.

Tan, Z., Rohrer, F., Lu, K., Ma, X., Bohn, B., Broch, S., Dong, H., Fuchs, H., Gkatzelis, G. I., Hofzumahaus, A., Holland, F., Li, X., Liu, Y., Liu, Y., Novelli, A., Shao, M., Wang, H., Wu, Y., Zeng, L., Hu, M., Kiendler-Scharr, A., Wahner, A., and Zhang, Y.: Wintertime photochemistry in Beijing: observations of ROx radical concentrations in the North China Plain during the BEST-ONE campaign, Atmos. Chem. Phys., 18, 12391-12411, https://doi.org/10.5194/acp-18-12391-2018, 2018.

Tan, Z., Lu, K., Jiang, M., Su, R., Wang, H., Lou, S., Fu, Q., Zhai, C., Tan, Q., Yue, D., Chen, D., Wang, Z., Xie, S., Zeng, L., and Zhang, Y.: Daytime atmospheric oxidation capacity in four Chinese megacities during the photochemically polluted season: a case study based on box model simulation, Atmos. Chem. Phys., 19, 3493-3513, https://doi.org/10.5194/acp-19-3493-2019, 2019.

Tang, X. Y.: The characteristics of urban air pollution in China, in Urbanization, energy, and air pollution in China: The challenges ahead, Proceedings of A Symposium, 47-54, DOI : 10.17226/11192, 2004.

Tang, Y., An, J., Wang, F., Li, Y., Qu, Y., Chen, Y., and Lin, J.: Impacts of an unknown daytime HONO source on the mixing ratio and budget of HONO, and hydroxyl, hydroperoxyl, and organic peroxy radicals, in the coastal regions of China, Atmos. Chem. Phys., 15, 9381-9398, https://doi.org/10.5194/acp-15-9381-2015, 2015.

Tian, Z., Yang, W., Yu, X., Zhang, M., Zhang, H., Cheng, D., Cheng, P., and Wang, B.: HONO pollution characteristics and nighttime sources during autumn in Guangzhou, China Environmental Science, 39 (05), 2000-2009, DOI: 10. 13227/j. hjkx. 201709269, 2018.

945 Tong, S., Hou, S., Zhang, Y., Chu, B., Liu, Y., He, H., Zhao, P., and Ge, M.: Comparisons of measured nitrous acid (HONO) concentrations in a pollution period at urban and suburban Beijing, in autumn of 2014, Science China Chemistry, 58, 1393-1402, https://doi.org/10.1007/s11426-015-5454-2, 2015.

Tong, S., Hou, S., Zhang, Y., Chu, B., Liu, Y., He, H., Zhao, P., and Ge, M.: Exploring the nitrous acid (HONO) formation mechanism in winter Beijing: direct emissions and heterogeneous production in urban and suburban areas, Faraday Discuss, 189, 213-230, https://doi.org/10.1039/C5FD00163C, 2016.

VandenBoer, T. C., Brown, S. S., Murphy, J. G., Keene, W. C., Young, C. J., Pszenny, A. A. P., Kim, S., Warneke, C., de Gouw, J. A., Maben, J. R., Wagner, N. L., Riedel, T. P., Thornton, J. A., Wolfe, D. E., Dubé, W. P., Öztürk, F., Brock, C. A., Grossberg, N., Lefer, B., Lerner, B., Middlebrook, A. M., and Roberts, J. M.: Understanding the role of the ground surface in HONO vertical structure: High resolution vertical profiles during NACHTT-11, Journal of Geophysical Research: Atmospheres, 118, 10,155-110,171, https://doi.org/10.1002/jgrd.50721, 2013.

VandenBoer, T. C., Young, C. J., Talukdar, R. K., Markovic, M. Z., Brown, S. S., Roberts, J. M., and Murphy, J. G.: Nocturnal loss and daytime source of nitrous acid through reactive uptake and displacement, Nature Geoscience, 8, 55-60, https://doi.org/10.1038/ngeo2298, 2015.

Villena, G., Kleffmann, J., Kurtenbach, R., Wiesen, P., Lissi, E., Rubio, M. A., Croxatto, G., and Rappenglück, B.: Vertical gradients of HONO, NOx and O3 in Santiago de Chile, Atmospheric Environment, 45, 3867-3873, https://doi.org/10.1016/j.atmosenv.2011.01.073, 2011.

Wang, G., Zhang, R., Gomez, M. E., Yang, L., Levy Zamora, M., Hu, M., Lin, Y., Peng, J., Guo, S., Meng, J., Li, J., Cheng, C., Hu, T., Ren, Y., Wang, Y., Gao, J., Cao, J., An, Z., Zhou, W., Li, G., Wang, J., Tian, P., Marrero-Ortiz, W., Secrest, J., Du, Z., Zheng, J., Shang, D., Zeng, L., Shao, M., Wang, W., Huang, Y., Wang, Y., Zhu, Y., Li, Y., Hu, J., Pan, B., Cai, L.,

965 Cheng, Y., Ji, Y., Zhang, F., Rosenfeld, D., Liss, P. S., Duce, R. A., Kolb, C. E., and Molina, M. J.: Persistent sulfate formation from London Fog to Chinese haze, Proceedings of the National Academy of Sciences, 113, 13630-13635, https://doi.org/10.1073/pnas.1616540113, 2016.

Wang, J., Zhang, X., Guo, J., Wang, Z., and Zhang, M.: Observation of nitrous acid (HONO) in Beijing, China: Seasonal variation, nocturnal formation and daytime budget, Science of The Total Environment, 587-588, 350-359, 970 https://doi.org/10.1016/j.scitotenv.2017.02.159, 2017.

Wang, S., Zhou, R., Zhao, H., Wang, Z., Chen, L., and Zhou, B.: Long-term observation of atmospheric nitrous acid (HONO) and its implication to local NO2 levels in Shanghai, China, Atmospheric Environment, 77, 718-724, https://doi.org/10.1016/j.atmosenv.2013.05.071, 2013. 
Wang, T., Wei, X. L., Ding, A. J., Poon, C. N., Lam, K. S., Li, Y. S., Chan, L. Y., and Anson, M.: Increasing surface ozone concentrations in the background atmosphere of Southern China, 1994-2007, Atmos. Chem. Phys., 9, 6217-6227, https://doi.org/10.5194/acp-9-6217-2009, 2009.

Weber, B., Wu, D., Tamm, A., Ruckteschler, N., Rodriguez-Caballero, E., Steinkamp, J., Meusel, H., Elbert, W., Behrendt, T., Sorgel, M., Cheng, Y., Crutzen, P. J., Su, H., and Poschl, U.: Biological soil crusts accelerate the nitrogen cycle through large NO and HONO emissions in drylands, Proceedings of the National Academy of Sciences, 112, 15384-15389, https://doi.org/10.1073/pnas.1515818112, 2015.

Wen, L., Chen, T., Zheng, P., Wu, L., Wang, X., Mellouki, A., Xue, L., and Wang, W.: Nitrous acid in marine boundary layer over eastern Bohai Sea, China: Characteristics, sources, and implications, Science of The Total Environment, 670, 282291, https://doi.org/10.1016/j.scitotenv.2019.03.225, 2019.

Wojtal, P., Halla, J. D., and McLaren, R.: Pseudo steady states of HONO measured in the nocturnal marine boundary layer: a conceptual model for HONO formation on aqueous surfaces, Atmos. Chem. Phys., 11, 3243-3261, https://doi.org/10.5194/acp-11-3243-2011, 2011.

Wong, K. W., Oh, H. J., Lefer, B. L., Rappenglück, B., and Stutz, J.: Vertical profiles of nitrous acid in the nocturnal urban atmosphere of Houston, TX, Atmos. Chem. Phys., 11, 3595-3609, https://doi.org/10.5194/acp-11-3595-2011, 2011.

Wong, K. W., Tsai, C., Lefer, B., Haman, C., Grossberg, N., Brune, W. H., Ren, X., Luke, W., and Stutz, J.: Daytime HONO vertical gradients during SHARP 2009 in Houston, TX, Atmos. Chem. Phys., 12, 635-652, https://doi.org/10.5194/acp-12-635-2012, 2012.

Wu, C., Wu, D., and Yu, J. Z.: Quantifying black carbon light absorption enhancement with a novel statistical approach, Atmos. Chem. Phys., 18, 289-309, https://doi.org/10.5194/acp-18-289-2018, 2018.

Wu, D., Horn, M. A., Behrendt, T., Muller, S., Li, J., Cole, J. A., Xie, B., Ju, X., Li, G., Ermel, M., Oswald, R., Frohlich-Nowoisky, J., Hoor, P., Hu, C., Liu, M., Andreae, M. O., Poschl, U., Cheng, Y., Su, H., Trebs, I., Weber, B., and Sorgel, M.: Soil HONO emissions at high moisture content are driven by microbial nitrate reduction to nitrite: tackling the HONO puzzle, ISME J, 13, 1688-1699, https://doi.org/10.1038/s41396-019-0379-y, 2019.

Xing, L., Wu, J., Elser, M., Tong, S., Liu, S., Li, X., Liu, L., Cao, J., Zhou, J., El-Haddad, I., Huang, R., Ge, M., Tie, X., Prévôt, A. S. H., and Li, G.: Wintertime secondary organic aerosol formation in Beijing-Tianjin-Hebei (BTH): contributions of HONO sources and heterogeneous reactions, Atmos. Chem. Phys., 19, 2343-2359, https://doi.org/10.5194/acp-19-2343$\underline{2019}, 2019$.

Xu, W., Kuang, Y., Zhao, C., Tao, J., Zhao, G., Bian, Y., Yang, W., Yu, Y., Shen, C., Liang, L., Zhang, G., Lin, W., and $\mathrm{Xu}, \mathrm{X}$. : NH3-promoted hydrolysis of NO2 induces explosive growth in HONO, Atmos. Chem. Phys., 19, 10557-10570, https://doi.org/10.5194/acp-19-10557-2019, 2019.

1005 Xu, Z., Wang, T., Wu, J., Xue, L., Chan, J., Zha, Q., Zhou, S., Louie, P. K. K., and Luk, C. W. Y.: Nitrous acid (HONO) in a polluted subtropical atmosphere: Seasonal variability, direct vehicle emissions and heterogeneous production at ground surface, Atmospheric Environment, 106, 100-109, https://doi.org/10.1016/j.atmosenv.2015.01.061, 2015.

Xue, C., Zhang, C., Ye, C., Liu, P., Catoire, V., Krysztofiak, G., Chen, H., Ren, Y., Zhao, X., Wang, J., Zhang, F., Zhang, C., Zhang, J., An, J., Wang, T., Chen, J., Kleffmann, J., Mellouki, A., and Mu, Y.: HONO Budget and Its Role in Nitrate

1010 Formation in the Rural North China Plain, Environ Sci Technol, 54, 11048-11057, https://doi.org/10.1021/acs.est.0c01832, 2020.

Xue, L., Gu, R., Wang, T., Wang, X., Saunders, S., Blake, D., Louie, P. K. K., Luk, C. W. Y., Simpson, I., Xu, Z., Wang, Z., Gao, Y., Lee, S., Mellouki, A., and Wang, W.: Oxidative capacity and radical chemistry in the polluted atmosphere of Hong Kong and Pearl River Delta region: analysis of a severe photochemical smog episode, Atmos. Chem. Phys., 16, 9891-

1015 9903, https://doi.org/10.5194/acp-16-9891-2016, 2016.

Yang, J., Shen, H., Guo, M.-Z., Zhao, M., Jiang, Y., Chen, T., Liu, Y., Li, H., Zhu, Y., Meng, H., Wang, W., and Xue, L.: Strong marine-derived nitrous acid (HONO) production observed in the coastal atmosphere of northern China, Atmospheric Environment, 244, 117948, https://doi.org/10.1016/j.atmosenv.2020.117948, $2021 \mathrm{a}$.

Yang, Q.: Observations and sources analysis of gaseous nitrous acid - A case study in Beijing and Pearl River Delta area, Ph.D. thsis, College of Environmental Sciences and Engineering, Peking University, China, 2014.

Yang, Q., Su, H., Li, X., Cheng, Y., Lu, K., Cheng, P., Gu, J., Guo, S., Hu, M., Zeng, L., Zhu, T., and Zhang, Y.: Daytime HONO formation in the suburban area of the megacity Beijing, China, Science China Chemistry, 57, 1032-1042, https://doi.org/10.1007/s11426-013-5044-0, 2014. 
Yang, W., Cheng, P., Tian, Z., Zhang, H., Zhang, M., and Wang, B.: Study on HONO pollution characteristics and daytime unknown sources during summer and autumn in Guangzhou, China., China Environmental Science, 37 (006), 20292039, DOI: 10.3969/j.issn.1000-6923.2017.06.005, 2017a.

Yang, W., Han, C., Zhang, T., Tang, N., Yang, H., and Xue, X.: Heterogeneous photochemical uptake of NO2 on the soil surface as an important ground-level HONO source, Environmental Pollution, 271, 116289, https://doi.org/10.1016/j.envpol.2020.116289, $2021 \mathrm{~b}$.

Yang, Y., Shao, M., Keßel, S., Li, Y., Lu, K., Lu, S., Williams, J., Zhang, Y., Zeng, L., Nölscher, A. C., Wu, Y., Wang, $\mathrm{X}$., and Zheng, J.: How the OH reactivity affects the ozone production efficiency: case studies in Beijing and Heshan, China, Atmos. Chem. Phys., 17, 7127-7142, https://doi.org/10.5194/acp-17-7127-2017, 2017b.

Yang, Y., Li, X., Zu, K., Lian, C., Chen, S., Dong, H., Feng, M., Liu, H., Liu, J., Lu, K., Lu, S., Ma, X., Song, D., Wang, W., Yang, S., Yang, X., Yu, X., Zhu, Y., Zeng, L., Tan, Q., and Zhang, Y.: Elucidating the effect of HONO on O3 pollution by a case study in southwest China, Science of The Total Environment, 756, 144127, https://doi.org/10.1016/j.scitotenv.2020.144127, 2021c.

Ye, C., Zhou, X., Pu, D., Stutz, J., Festa, J., Spolaor, M., Cantrell, C., Mauldin, R. L., Weinheimer, A., and Haggerty, J.: ATMOSPHERIC SCIENCE. Comment on "Missing gas-phase source of HONO inferred from Zeppelin measurements in the troposphere", Science, 348, 1326, DOI: 10.1126/science.aaa1992, 2015.

Ye, C., Gao, H., Zhang, N., and Zhou, X.: Photolysis of Nitric Acid and Nitrate on Natural and Artificial Surfaces, Environ Sci Technol, 50, 3530-3536, https://doi.org/10.1021/acs.est.5b05032, 2016.

Ye, C., Zhang, N., Gao, H., and Zhou, X.: Photolysis of Particulate Nitrate as a Source of HONO and NOx, Environmental Science \& Technology, 51, 6849-6856, https://doi.org/10.1021/acs.est.7b00387, 2017.

Yue, D. L., Hu, M., Wu, Z. J., Guo, S., Wen, M. T., Nowak, A., Wehner, B., Wiedensohler, A., Takegawa, N., Kondo, Y., Wang, X. S., Li, Y. P., Zeng, L. M., and Zhang, Y. H.: Variation of particle number size distributions and chemical compositions at the urban and downwind regional sites in the Pearl River Delta during summertime pollution episodes, Atmos. Chem. Phys., 10, 9431-9439, https://doi.org/10.5194/acp-10-9431-2010, 2010.

Yue, D. L., Zhong, L., Shen, J., Zhang, T., Zhou, Y., Zeng, L., and Dong, H.: Pollution properties of atmospheric HNO2 and its effect on $\mathrm{OH}$ radical formation in the PRD region in autumn, Environmental Science \& Technology, 162-166, DOI: 10.3969/j.issn.1003-6504.2016.02.030, 2016.

Yun, H., Wang, Z., Zha, Q., Wang, W., Xue, L., Zhang, L., Li, Q., Cui, L., Lee, S., Poon, S. C. N., and Wang, T.: Nitrous acid in a street canyon environment: Sources and contributions to local oxidation capacity, Atmospheric Environment, 167, 223-234, https://doi.org/10.1016/j.atmosenv.2017.08.018, 2017.

Zhang, B., and Tao, F.-M.: Direct homogeneous nucleation of NO2, H2O, and NH3 for the production of ammonium nitrate particles and HONO gas, Chemical Physics Letters, 489, 143-147, https://doi.org/10.1016/j.cplett.2010.02.059, 2010.

Zhang, J., An, J., Qu, Y., Liu, X., and Chen, Y.: Impacts of potential HONO sources on the concentrations of oxidants and secondary organic aerosols in the Beijing-Tianjin-Hebei region of China, Science of The Total Environment, 647, 836852, https://doi.org/10.1016/j.scitotenv.2018.08.030, 2019a.

Zhang, L., Wang, T., Zhang, Q., Zheng, J., Xu, Z., and Lv, M.: Potential sources of nitrous acid (HONO) and their impacts on ozone: A WRF-Chem study in a polluted subtropical region, Journal of Geophysical Research: Atmospheres, 121, 3645-3662, https://doi.org/10.1002/2015JD024468, 2016.

Zhang, N., Zhou, X., Shepson, P. B., Gao, H., Alaghmand, M., and Stirm, B.: Aircraft measurement of HONO vertical profiles over a forested region, Geophysical Research Letters, 36, https://doi.org/10.1029/2009GL038999, 2009.

Zhang, W., Tong, S., Ge, M., An, J., Shi, Z., Hou, S., Xia, K., Qu, Y., Zhang, H., Chu, B., Sun, Y., and He, H.: Variations and sources of nitrous acid (HONO) during a severe pollution episode in Beijing in winter 2016, Science of The Total Environment, 648, 253-262, https://doi.org/10.1016/j.scitotenv.2018.08.133, 2019b.

Zheng, J., Shi, X., Ma, Y., Ren, X., Jabbour, H., Diao, Y., Wang, W., Ge, Y., Zhang, Y., and Zhu, W.: Contribution of nitrous acid to the atmospheric oxidation capacity in an industrial zone in the Yangtze River Delta region of China, Atmos. Chem. Phys., 20, 5457-5475, https://doi.org/10.5194/acp-20-5457-2020, 2020.

1070 Zhong, L., Louie, P. K. K., Zheng, J., Yuan, Z., Yue, D., Ho, J. W. K., and Lau, A. K. H.: Science-policy interplay: Air quality management in the Pearl River Delta region and Hong Kong, Atmospheric Environment, 76, 3-10, https://doi.org/10.1016/j.atmosenv.2013.03.012, 2013. 
Zhou, X., Civerolo, K., Dai, H., Huang, G., Schwab, J., and Demerjian, K.: Summertime nitrous acid chemistry in the atmospheric boundary layer at a rural site in New York State, Journal of Geophysical Research: Atmospheres, 107, ACH 1311-ACH 13-11, https://doi.org/10.1029/2001JD001539, 2002a.

Zhou, X., He, Y., Huang, G., Thornberry, T. D., Carroll, M. A., and Bertman, S. B.: Photochemical production of nitrous acid on glass sample manifold surface, Geophysical Research Letters, 29, 26-21-26-24, https://doi.org/10.1029/2002GL015080, 2002b.

Zhou, X., Gao, H., He, Y., Huang, G., Bertman, S. B., Civerolo, K., and Schwab, J.: Nitric acid photolysis on surfaces in 1080 low-NOx environments: Significant atmospheric implications, Geophysical Research Letters, 30, https://doi.org/10.1029/2003GL018620, 2003.

Zhou, X., Huang, G., Civerolo, K., Roychowdhury, U., and Demerjian, K. L.: Summertime observations of HONO, $\mathrm{HCHO}$, and $\mathrm{O} 3$ at the summit of Whiteface Mountain, New York, Journal of Geophysical Research: Atmospheres, 112, https://doi.org/10.1029/2006JD007256, 2007.

1085 Zhou, X., Zhang, N., TerAvest, M., Tang, D., Hou, J., Bertman, S., Alaghmand, M., Shepson, P. B., Carroll, M. A., Griffith, S., Dusanter, S., and Stevens, P. S.: Nitric acid photolysis on forest canopy surface as a source for tropospheric nitrous acid, Nature Geoscience, 4, 440-443, https://doi.org/10.1038/ngeo1164, 2011.

Ziemba, L. D., Dibb, J. E., Griffin, R. J., Anderson, C. H., Whitlow, S. I., Lefer, B. L., Rappenglück, B., and Flynn, J.: Heterogeneous conversion of nitric acid to nitrous acid on the surface of primary organic aerosol in an urban atmosphere, 